Southern Methodist University

SMU Scholar

\title{
An 'I Do' I Choose: How the Fight for Marriage Access Supports a Per Se Finding of Persecution for Asylum Cases Based on Forced Marriage
}

Natalie Nanasi

Southern Methodist University, Dedman School of Law 


\section{AN "I DO" I CHOOSE: HOW THE FIGHT FOR MARRIAGE ACCESS SUPPORTS A PER SE FINDING OF PERSECUTION FOR ASYLUM CASES BASED ON FORCED MARRIAGE}

\section{NATALIE NANASI*}

Because it fulfils yearnings for security, safe haven, and connection that express our common humanity, civil marriage is an esteemed institution, and the decision whether and whom to marry is among life's momentous acts of self-definition.

- Goodridge v. Department of Public Health'

\section{INTRODUCTION}

In the summer of 2013 , the country waited anxiously for the Supreme Court to issue rulings in two landmark gay marriage cases that had the potential to fundamentally alter the institution of marriage in the United States. Advocates and opponents of same-sex unions fiercely debated the issue, but although the two sides' positions were widely divergent, each emphasized the unique role of marriage in the social, personal, and legal fabric of life. Edie Windsor, the named plaintiff in the lawsuit ${ }^{2}$ seeking to strike down $\S 3$ of the Defense

* Practitioner-in-Residence and Director of the Domestic Violence Clinic at American University, Washington College of Law. I am extremely grateful to Anju Gupta, Elizabeth Keyes, David Koplow, Jaya Ramji-Nogales, and Nancy Polikoff for their thoughtful review and comments. The insights obtained from Alex Aleinikoff, Benjamin Barton, Angela Cornell, Rachel López, Stephen Meili, Michelle Pistone, Amy Senier, and Diane Uchimiya truly benefited this piece and I thank them along with the conveners and organizers of the 2013 Clinical Law Review Workshop and the 2014 Immigration Law Professors Workshop. I also owe a debt of gratitude to Kerry Abrams and my colleagues at the Washington College of Law for their direction and support during the conceptual stages of this article. Additionally, I wish to acknowledge Lauren Allen and Angela Cabral for their invaluable research and editorial assistance as well as Cat Kim and the editors of the Columbia Journal of Gender and Law for their thoughtful edits. Finally, thank you to Justin Koplow, without whom my understanding of the profound nature of the institution of marriage would be incomplete.

1798 N.E.2d 941, 955 (Mass. 2003).

2 United States v. Windsor, 133 S.Ct. 2675 (2013). 
of Marriage Act (DOMA), ${ }^{3}$ agreed. Ms. Windsor had been in a committed relationship with her partner for forty years prior to their marriage in $2007 . .^{4}$ Yet she stated that the transformation after entering into the legal union "was profound" and that she has "asked everybody since who gets married after long-term relationships, 'Did it feel different the next day?' and the answer is always 'Yes, absolutely."'s

Ms. Windsor's words were moving but far from novel. Her sentiments echoed decades of Supreme Court decisions that have recognized marriage as not merely a "constitutionally protected ... relationship" but an institution that is "fundamental to our very existence and survival" and "intimate to the degree of being sacred".

The consistent reverence for the marital relationship expressed by the Supreme Court in the domestic sphere, however, stands in stark contrast to the treatment of marriage by courts interpreting asylum law, specifically in the context of cases involving women ${ }^{9}$ seeking protection in the United States from forced marriage. Although the underlying law and administrative agency interpretations support a finding that forced marriage is a persecutory act, courts analyzing whether entry into marriage against one's will can be a basis for asylum have rejected the notion of forced marriage as a harm rising to the level of persecution.

In general, a woman fleeing a forced marriage will likely obtain asylum protection only

3 Defense of Marriage Act $\S 3,1$ U.S.C. $§ 7$ (1996), invalidated by Windsor, 133 S.Ct. 2675. The Defense of Marriage Act contains two operative sections. Section 2 allows states to refuse to recognize same-sex marriages performed under the laws of other states. Section 3, which was at issue in U.S. v. Windsor, defines the term marriage as a legal union between one man and one woman and the word spouse as "a person of the opposite sex who is a husband or a wife."

4 Windsor, 133 S.Ct. at 2683.

5 Nina Totenberg, Meet The 83-Year-Old Taking On The U.S. Over Same-Sex Marriage, NaT'L Pub. Radio (Mar. 21, 2013, 4:36 PM), http://www.npr.org/2013/03/21/174944430/meet-the-83-year-old-taking-on-the-us-over-same-sex-marriage[http://perma.cc/L8RH-FCWC].

6 Turner v. Safley, 482 U.S. 78, 96 (1987).

7 Loving v. Virginia, 388 U.S. 1, 12 (1967).

8 Griswold v. Connecticut, 381 U.S. 479, 486 (1965).

9 Female pronouns are used throughout this article because of the greater frequency (and often the greater harm) of forced marriage inflicted upon women, but it is noteworthy that men, too, may be victims of forced marriage. See Yunas Samad, Forced Marriage Among Men: An Unrecognized Problem, 30 Critical Soc.

PoL'y 189-207 (2010). 
if her narrative fits one of two accepted frameworks - what I will call here the "Violent Honor Crime Story" and the "Abusive Elderly Polygamist Story"-both of which focus not on the harm of forced marriage itself but on associated persecutory acts. If her claim is structured around the former narrative, the retaliation she will face at the hands of her family if she resists the marriage (a so-called "honor crime"10), she can make a relatively straightforward application for relief based on her fear of future physical harm. Alternatively, in the latter framework, if she is able to provide certain details about the nature of the marriage that she will be forced into-for example, that she will be entering into a polygamous union with a distant relative who is significantly older than she and is known in her community as being physically abusive to his existing wives-asylum may be granted based on these "component parts" of the forced marriage."

But what about women who cannot provide such information or do not fit neatly into these existing legal categories? Can U.S. asylum law provide a safe haven for a woman who is being forced to marry a man about whom she knows little or nothing, when she cannot prove that attendant forms of persecution such as domestic violence, marital rape, or deprivations of liberty will occur? Put another way, can forced marriage standing alone be a per se basis for a finding of persecution sufficient to merit asylum protection? An analysis of the current state of asylum law suggests that under prevailing judicial interpretations, such a case would be doomed to failure, as U.S. courts interpreting asylum law would refuse to recognize the persecutory nature of the forced marriage itself. U.S. courts regularly reject the notion that forcing a woman to enter into what is arguably life's most important

10 An honor crime is an act "of violence, usually murder, committed by male family members against female family members who are perceived to have brought dishonor upon the family." Oral Intervention at the 57th Session of the UN Commission on Human Rights, Item 12 - Integration of the human rights of women and the gender perspective: Violence Against Women and "Honor" Crimes, Human Rights Watch (Apr. 6, 2001), http://www.hrw.org/news/2001/04/05/item-12-integration-human-rights-women-and-gender-perspectiveviolence-against-women [http://perma.cc/3YEU-L9WH]; see also Wendy M. Gonzalez, Karo Kari: Honor Killing, 9 BufF. WomeN's L. J. 22 (2001). "Dishonorable acts" that typically lead to honor violence include "seeking divorce, adultery, premarital sexual relations, premarital pregnancy, or being the victim of a sexual assault or rape." Mazna Hussain, Take My Riches, Give Me Justice: A Contextual Analysis of Pakistan's Honor Crimes Legislation, 29 HARv. J.L. \& Gender 223, 225-26 (2006). The United Nations Population Fund has estimated that as many as five thousand women are killed worldwide every year in the name of honor. U.N. POPULATION Fund, Chapter 3: Ending Violence against Women and Girls: A Human Rights and Health Priority, in The State of World Population 2000: Lives Together, Worlds Apart: Men and Women in A Time of Change (2000),http://www.unfpa.org/swp/2000/english/ch03.html [http://perma.cc/99B7-L7QT]. Many others are subjected to alternative forms of violence, including beatings, acid attacks, maiming or the cutting off of appendages, or rape. Hussain, supra, at 225-26.

11 See Kim Thuy Seelinger, Forced Marriage and Asylum: Perceiving the Invisible Harm, 42 Colum. Hum. RTS. L. REv. 55, 57 (2010). 
relationship against her will, and thereby also inflicting the related harm of preventing her from choosing a spouse with whom to spend her life, is a significant deprivation rising to the level of persecution, even without the presence of ancillary harms.

Building on existing scholarship that analyzes issues at the intersection of gender, familial relationships, and immigration and family law, ${ }^{12}$ and more specifically, the literature that challenges the disparate treatment of gender-based claims in asylum law, ${ }^{13}$ this

12 See, e.g., Nancy F. Cott, Public Vows: A History of Marriage and the Nation 132-55 (2000) (providing a historical overview of the interrelationship of marriage and immigration in the United States); Kerry Abrams, Immigration Law and the Regulation of Marriage, 91 MINN. L. REv. 1625 (2007) (mapping immigration law's regulation of the four critical phases of the marital relationship: courtship, entry into marriage, the intact marriage itself, and exit from marriage); Jennifer M. Chacón, Citizenship and Family: Revisiting Dred Scott, 27 WASH. U. J.L. \& PoL'y 45 (2008) (using the Dred Scott case, 60 U.S. 393 (1857), to explore modern questions about the impact of U.S. immigration law and policy on family unity); Jennifer M. Chacón, Loving Across Borders: Immigration Law and the Limits of Loving, 2007 WIS. L. Rev. 345 (2007) (demonstrating that even after anti-miscegenation laws were held unconstitutional in Loving $v$. Virginia, the government continues to regulate intimate relationships and perpetuate racial hierarchies through immigration law); Kristin Collins, When Fathers' Rights Are Mothers 'Duties: The Failure of Equal Protection in Miller v. Albright, 109 YALE L.J. 1669 (2000) (analyzing a Supreme Court case that addressed gender inequality in the ability to transmit citizenship to foreign-born, non-marital children); Hiroshi Motomura, We Asked for Workers, but Families Came: Time, Law, and the Family in Immigration and Citizenship, 14 VA. J. Soc. PoL'Y \& L. 103 (2006) (examining the role of the family in immigration law, jus soli citizenship, and the integration of immigrants); Hiroshi Motomura, The Family and Immigration: $A$ Roadmap for the Ruritanian Lawmaker, 43 AM. J. Comp. L. 511 (1995) (identifying the significant questions that a system of immigration and citizenship law must answer when considering the family); Rose Cuison Villazor, The Other Loving: Uncovering the Federal Government's Racial Regulation of Marriage, 86 N.Y.U. L. Rev. 1361 (2011) (describing how a combination of immigration, citizenship, and military laws led to restrictions on the marriages of white American soldiers and local Japanese women after World War II); Leti Volpp, Divesting Citizenship: On Asian American History and the Loss of Citizenship Through Marriage, 53 UCLA L. Rev. 405 (2005) (describing and analyzing a history of gender- and race-based exclusion).

13 See, e.g., Pamela Goldberg, Analytical Approaches in Search of Consistent Application: A Comparative Analysis of the Second Circuit Decisions Addressing Gender in the Asylum Law Context, 66 Brook. L. Rev. 309 (2000) (examining the Second Circuit's disparate analytical approaches in three gender-based asylum claims); Karen Musalo \& Stephen Knight, Unequal Protection: When Women Are Persecuted, It's Often Described as a Cultural Norm Rather than a Reason to Grant Asylum, Bull. Atomic Scientists Nov.-Dec. 2002, at 56 (describing U.S. courts' resistance to, and erratic treatment of, gender-based asylum claims, as compared to the approaches of other countries and in international law); Melanie Randall, Refugee Law and State Accountability for Violence Against Women: A Comparative Analysis of Legal Approaches to Recognizing Asylum Claims Based on Gender Persecution, 25 HARV. Women's L.J. 281 (2002) (discussing the Canadian response to gender-based asylum claims, specifically, social group analysis and the role of the state in protecting women from gender-based harm); Jenny-Brooke Condon, Asylum Law's Gender Paradox, 33 Seton Hall L. REv. 207 (2002) (highlighting the heightened burden imposed on female asylum applicants due to the lack of inclusion of gender in the refugee definition's enumerated grounds of protection). 
Article explores the disconnect that exists between domestic constitutional jurisprudence and immigration case law when evaluating the importance of marriage. Drawing on both international law and the evolution of U.S. constitutional law regarding marriage equality toward an unequivocal recognition of the right to marry the person of one's choice as a fundamental right, this paper argues that U.S. asylum law can, and should, recognize forced marriage itself as a persecutory act and provide protection to those seeking refuge from this obvious harm.

Part I assesses the limitations of U.S. asylum law as it relates to forced marriage. First focusing on the definition of persecution, it explains how the broadly-defined term - which has been held to include physical harm as well as abuses such as those that are economic or emotional or that constitute violations of fundamental beliefs or human rights-is incorrectly applied in the forced marriage context. This occurs both because immigration and federal courts routinely and erroneously conflate forced marriage with arranged marriage and categorize applicants' valid claims of persecution as mere harassment. This section also demonstrates that because the problem of forced marriage occurs in the context of family, inconsistency has emerged in the analysis of both persecution and the related concept of "nexus." Courts regularly ignore well-established legal theories such as mixed-motives for persecution and inappropriately characterize persecutors' motives as aberrational or private acts. Finally, Part I concludes by discussing Gao v. Gonzales ${ }^{14}$ the only published federal case granting asylum to a victim of forced marriage, and argues that although the case is a positive step in courts' recognition of forced marriage-based asylum claims, its impact has been limited by its procedural history.

Part II provides an overview of the development of U.S. law surrounding the institution of marriage and demonstrates that domestic constitutional law unequivocally considers the right to marry the person of one's choice to be a fundamental right worthy of significant protection. It describes how progress in law and society since the eighteenth century has led to both the requirement of choice and consent in marriage and the recognition of the marital union as a relationship based on emotion that forms the foundation of modern society. This understanding of marriage was the basis of the U.S. Supreme Court's support of the right to marry for disadvantaged populations, such as prisoners and the poor, and its proclamation that "marriage is one of the "basic civil rights of man"'15 when striking down an anti-miscegenation statute and affirming the constitutional right to enter into marriage

14440 F.3d 62 (2d Cir. 2006), cert. granted, judgment vacated sub nom. Keisler v. Hong Yin Gao, 552 U.S. 801 (2007).

15 Loving, 388 U.S. at 12. 
with the person of one's choosing in Loving $v$. Virginia. In the years after Loving, judicial support for access to marriage continued, as state courts began to grant same-sex couples the right to marry, holding that restricting access to marriage was unconstitutional because it both prevented entry into a uniquely meaningful relationship and denied access to a host of associated legal rights. Most recently, the U.S. Supreme Court reaffirmed its view of the inherent dignity of the marital relationship by striking down the Defense of Marriage Act's discriminatory treatment of legally wed same-sex couples. ${ }^{16}$

Part III reveals how the treatment of forced marriage in international law diverges significantly from that of U.S. courts interpreting asylum law. It describes how numerous international instruments-including the Universal Declaration of Human Rights, the International Convention of Civil and Political Rights, and the Convention on the Elimination of All Forms of Discrimination Against Women-consider free and full consent to be an essential element of a valid marriage, and therefore, unlike U.S. courts adjudicating asylum petitions, consider forced marriage to be a violation of human rights.

With Parts II and III having established a foundation for respect for marriage in U.S. and international law, Part IV returns to an analysis of asylum law and argues that international law and advances in U.S. constitutional law should guide courts' decision-making in asylum cases based on forced marriage. International law's insistence on consent in marriage clearly establishes that a forced marriage is a violation of international human rights norms. Domestic law's increasing recognition of the unique significance of the marital relationship and protection for the right to marry a person of one's choosing also highlight flaws in courts' reasoning in the asylum context, where forced marriage is not considered a sufficiently harmful act such that its victims merit protection. As forced marriage both devalues marriage and prevents an individual from exercising choice in whom they do and do not marry, this Article concludes by contending that immigration and federal courts interpreting asylum law should adhere to international and constitutional law standards and adopt a per se rule that forced marriage constitutes persecution.

\section{Forced Marriage as a Basis for Asylum}

\section{A. Distinguishing Between Forced Marriage and Arranged Marriage}

Any examination of the issue of forced marriage first requires a preliminary discussion about terminology in order to differentiate between the interrelated but often wrongly un- 
distinguished concepts of forced marriage and arranged marriage. The U.S. State Department provides a helpful starting point in its Foreign Affairs Manual, which makes

a very clear distinction between a forced marriage and an arranged marriage. In arranged marriages, the families of both spouses take a leading role in arranging the marriage but the choice whether to accept the arrangement remains with the individuals. In a forced marriage, at least one party does not consent or is unable to give informed consent to the marriage, and some element of duress is generally present. ${ }^{17}$

The distinction made by the U.S. government is echoed by the British government's U.K. Foreign \& Commonwealth Office, ${ }^{18}$ which explains that "a forced marriage is a marriage where one or both people do not ... consent to the marriage and pressure or abuse is used," unlike an arranged marriage, where "families take a leading role in choosing the marriage partner, but the choice of whether to enter the marriage is left to both people."19

Of course, these issues are rarely black and white, and whether a marriage is considered forced or arranged often involves an element of subjectivity in which the complex issues of culture and family dynamics take center stage. As Karma Nirvana, a leading anti-forced marriage advocacy organization, recognizes, "[t]here can be a very thin line between arranged marriage and forced marriage." 20 Perhaps the most accurate way to conceive of the distinction is not as a bright line between the two forms of marriage but as a continuum, with arranged and forced marriage on either end and a vast area of grey in between. Karma Nirvana describes the "slippery slope" between arranged and forced marriage, explaining that a marriage can even

17 U.S. Dep't. State. Foreign Affairs Manual, 7 FAM 1459(b)-(c) (2005).

18 The Foreign \& Commonwealth Office in the United Kingdom is charged with functions similar to those of the State Department of the United States. The definitions utilized by the U.K. government are described here because the United Kingdom has developed a sophisticated and highly coordinated response to prevent and redress forced marriage, including passage of the Forced Marriage (Civil Protection) Act, 2007, c. 20 (U.K.), the creation of a dedicated Forced Marriage Unit to assist survivors, and the production of a number of outreach and training materials for potential victims and first responders.

19 What is a Forced Marriage?, Foreign \& Commonwealth OfFice, https://www.gov.uk/government/ uploads/system/uploads/attachment_data/file/70154/Forced_Marriage_Unit_what_is_forced_marriage_ leaflet.pdf [http://perma.cc/K453-KYBR] (last visited Jun. 2, 2014).

20 FAQ's: Grey Area?, KARMA NIRVANA, http://www.karmanirvana.org.uk/faqs/ [http://perma.cc/ARK35XR3] (last visited Apr. 20, 2014). 
start out as 'arranged' but, if the person changes his/her mind at any time during the preparations ... even on the wedding day ... [t] hey have the right to pull out. If the person is made to 'keep their word' to go ahead with the marriage, the marriage ceases to be a free choice and becomes 'forced'. ${ }^{21}$

The key element in the analysis, however, remains the presence or absence of choice. ${ }^{22}$ Put most succinctly, "[t]here is no compulsion in an arranged marriage." 23

Although a precise definition of forced marriage may ultimately be difficult to determine, the factors leading to forced marriage and the devastating effects of the practice on its victims are clear. According to the Asylum Division of the United States Citizenship and Immigration Services (USCIS), "forced marriage takes place throughout the world and occurs for a variety of reasons stemming from issues such as poverty, gender discrimination, and lack of security." ${ }^{24}$ The British Government's Forced Marriage Unit elaborates by identifying several potential motives of families forcing their daughters into marriage, including strengthening family ties, achieving financial gain (e.g., selling a daughter to alleviate financial burden or settle a debt), ensuring that land and property remain within a family, responding to family pressure, and protecting religious and cultural ideals. ${ }^{25}$ Forced marriage is also often perpetrated in order to enforce gender roles, including marrying daughters to maintain control over their sexuality, to protect them from rape, or even, per-

\section{Id.}

22 In considering whether "choice" exists, it is important to remember that the freedom of one's choice can be impacted by familial and cultural influences that range in severity from psychological (e.g., emotional blackmail) and financial pressure to threats and physical abuse or other violence. See What is a Forced Marriage?, supra note 19 ("The pressure put on people to marry against their will can be physical (including threats, actual physical violence and sexual violence) or emotional and psychological (for example, when someone is made to feel like they're bringing shame on their family. Financial abuse (taking your wages or not giving you any money) can also be a factor.").

23 FAQ's: Grey Area? supra note 20.

24 U.S. Citizenship \& Immigration Servs. Asylum Div., Lesson 26: Female Asylum Applicants and GenderRelated Claims, in Asylum Officer Basic Training Course 14 (2009), available at http://www.uscis.gov/ USCIS/Humanitarian/Refugees\%20\&\%20Asylum/Asylum/AOBTC\%20Lesson\%20Plans/Female-AsylumApplicants-Gender-Related-Claims-31 aug 10.pdf [http://perma.cc/HC7V-3ZXP] [hereinafter AOBTC].

25 Forced Marriage Unit, Multi-Agency Practice Guidelines: Handling Cases of Forced Marriage 11 (2009), available at https://www.gov.uk/government/uploads/system/uploads/attachment_data/file/35530/ forced-marriage-guidelines09.pdf [http://perma.cc/Q86Q-99V7] [hereinafter MULTI-AGENCY GUIDELINES]. 
versely, to exonerate rapists. ${ }^{26}$

Regardless of the underlying reason, when a marriage is entered into without mutual consent or under duress, severe and significant violations of human rights frequently follow. Forced marriage "provides an arena in which sexual abuse, sexual exploitation, domestic violence, forced labor, and slavery often go unnoticed. Women in forced marriages may have fewer educational and work opportunities and their freedom of movement may be restricted. ${ }^{27}$ As addressed in the Introduction and as will be discussed in detail in Part IV below, eligibility for asylum protection in the United States for individuals facing these attendant harms of forced marriage can be relatively straightforward. However, courts considering asylum claims have not yet recognized what international law, domestic constitutional law, and even administrative agencies have long understood, that marriage is a fundamental human right and that forced marriage, or the inability to choose one's spouse, is $i t s e l f$ a violation constituting persecution.

\section{B. Persecution and Nexus in Forced Marriage Asylum Cases}

To be eligible for asylum, an applicant must meet the definition of a refugee set forth in Section 101(a)(42) of the Immigration and Nationality Act (INA):

any person who is outside any country of such person's nationality ... who is unable or unwilling to return to, and is unable or unwilling to avail himself or herself of the protection of, that country because of persecution or a well-founded fear of persecution on account of race, religion, nationality, membership in a particular social group, or political opinion. ${ }^{28}$

Whether an individual qualifies as a refugee requires a complex legal analysis. The para-

26 See Morgan McDaniel, From Morocco to Denmark: Rape survivors around the world are forced to marry attackers, WOMEN's MEDIA CENTER (May 2, 2013), http:/www.womenundersiegeproject.org/blog/entry/frommorocco-to-denmark-rape-survivors-around-the-world-are-forced-to-marry [http://perma.cc/8AWY-YCUW].

27 AOBTC, supra note 24, Lesson 26 at 14. See also Multi-Agency Guidelines, supra note 25 at 13 ("Women trapped in a forced marriage often suffer violence, rape, forced pregnancy and forced childbearing. Many girls and young women are withdrawn from education early. . . . Their interrupted education limits their career choices. Even if the woman manages to find work, however basic, they may be prevented from taking the job or their earnings may be taken from them. This leads to economic dependence, which makes the possibility of leaving the situation even more difficult. Some may be unable to leave the house unescortedliving virtually under "house arrest."').

28 Immigration and Nationality Act $\S 101(a)(42), 8$ U.S.C.A. $\S 1101(a)(42)$ (West 2013). 
graph-long definition above is the subject of countless court decisions, scholarly articles, and law school courses. This Article will therefore focus only on two discrete areas of asylum law that are central to the examination of forced marriage cases: the question of what constitutes "persecution," and the related requirement of establishing "nexus," or that the applicant's past or feared persecution is "on account of" one of the five protected characteristics enumerated in the refugee definition.

The Board of Immigration Appeals (BIA), the highest administrative body that interprets immigration laws, has not issued any precedential decisions specifically on the issue of forced marriage as a basis for asylum. Most U.S. circuit courts have also not substantively addressed the issue, declining to reach the merits based on procedural, jurisdictional, evidentiary, or credibility grounds..$^{29}$ Others have dismissed cases based on a lack of evidence that the governments of the applicants' home countries were "unable or unwilling"30 to protect them. ${ }^{31}$ Often, the issue of forced marriage is sidelined in favor of addressing more easily justiciable gender-based claims. For example, in the landmark case of Matter of Kasinga, which was the first to recognize female genital mutilation (FGM) as a basis for asylum in the United States and served as a precedent for acceptance of gender-based claims generally, the forced marriage that was central to Ms. Kasinga's story and claim was dismissed in one sentence as an "alternate claim," and listed under the heading "Ancillary

29 See, e.g., Pulei v. Holder, 392 F. App'x 586 (9th Cir. 2010) (denied on credibility grounds); Yuexian Liu v. U.S. Att'y. Gen., 271 F. App'x 947 (11th Cir. 2008) (denying asylum due to lack of jurisdiction and on procedural grounds); Dieng v. Mukasey, 284 F. App'x 2 (4th Cir. 2008) (denying asylum on credibility grounds); Keita v. Gonzales, 175 F. App'x 711 (6th Cir. 2006) (denying asylum due to lack of corroborating evidence); Pan v. Gonzales, 445 F.3d 60 (Ist Cir. 2006) (denying asylum due to insufficient evidence).

30 An individual seeking asylum in the United States must demonstrate that the government of her home country is either the persecutory actor or, in the cases of non-governmental actors, that the government was "unable or unwilling" to protect her from persecution. See Matter of Acosta, 19 I. \& N. Dec. 211, 222 (B.I.A. 1985), overruled on other grounds by Matter of Mogharrabi, 19 I. \& N. Dec. 439 (B.I.A. 1987) (construing persecution as requiring that the claimed harm must be inflicted by the government of a country or by persons that the government is unable or unwilling to control).

31 See, e.g., Berishaj v. Gonzales, 238 F. App'x 57 (6th Cir. 2007) (denying asylum because the perpetrator was jailed, demonstrating that the government was able to provide protection); Keita v. Gonzales, 175 F. App'x 711 (6th Cir. 2006) (denying asylum because, in part, the applicant did not attempt to seek protection from the police). 
Matters." ${ }^{32}$ On the few occasions that the issue of forced marriage has been substantively addressed, nearly all courts have denied asylum based on one of the two issues noted above, either an inability to demonstrate that the harm experienced or feared rises to the level of persecution or the related concept of nexus. Each of these issues will be addressed in turn below.

\section{Persecution}

An individual seeking asylum protection in the United States must demonstrate that she has been persecuted in the past or that she fears persecution in the future. The term "persecution" is a broad one that is not defined in the INA; the BIA also has not provided a precise definition. The most widely accepted understanding of the term comes from Matter of Acosta, which defines persecution as "harm or suffering that is inflicted upon an individual in order to punish him for possessing a belief or characteristic a persecutor seeks to overcome." ${ }^{33}$ Acosta was later modified to make clear that punitive or malignant intent is not required; in other words, persecution can exist whether or not the persecutor intends the victim to experience harm. ${ }^{34}$

Lacking clear guidance, most federal circuit courts have created their own definitions of persecution. As a threshold matter, all jurisdictions agree on what persecution is not. "To qualify as persecution, a person's experience must rise above unpleasantness, harassment, and even basic suffering." 35 Similarly, "low-level intimidation and harassment" is insuf-

32 In re Kasinga, 21 I. \& N. Dec. 357, 368 (B.I.A. 1996) (the full "Ancillary Matters" section reads as follows: "[i]n view of our disposition of the applicant's case, we will deny the INS's request to remand. We find it unnecessary to consider the new evidentiary materials submitted by the applicant on appeal. We also do not reach the applicant's alternate claim that she has a well-founded fear of persecution on the basis of a forced polygamous marriage. Moreover, it is unnecessary for us to adjudicate the applicant's application for withholding of deportation.") (emphasis added).

3319 I. \& N. Dec. at 222, overruled on other grounds by Matter of Mogharrabi, 19 I. \& N. Dec. 439 (B.I.A. 1987).

34 In re Kasinga, 21 I. \& N. Dec. at 365 . For example, the family members who sought have Ms. Kasinga undergo female genital mutilation likely did not intended to harm her. To the contrary, they probably believed that subjecting Ms. Kasinga to the practice would be a benefit to her, as it would "purify" her, prepare her for marriage, and make her a better wife and mother. See, e.g., World Health Org., Female Genital MUTILATION INFORMATION KIT 8 (1999), available at http://apps.who.int/iris/bitstream/10665/65858/1/WHO_ CHS_WMH_99.11.pdf.[http://perma.cc/D53U-MDPL] ("The reasons given to justify FGM are ... purification; family honour; hygiene (cleanliness); prevention of promiscuity; increasing sexual pleasure for the husband; . .. enhancing fertility; and increasing matrimonial opportunities.").

35 Jorgji v. Mukasey, 514 F.3d 53, 57 (1st Cir. 2008) (quoting Nelson v. INS, 232 F.3d 258, 263 (Ist Cir. 
ficient to merit protection. ${ }^{36}$ Discrimination also does not constitute persecution, except in extraordinary circumstances. ${ }^{37}$ Courts also generally find agreement at the other end of the spectrum, in that the standard for what constitutes persecution is undeniably met by extreme acts such as "the infliction or threat of death, torture, or injury to one's person or freedom. ${ }^{" 38}$

The middle ground-the vast expanse between harassment and torture-is where most litigated cases fall. To begin to narrow the definition, it is undisputed that physical harm is not required for a court to find persecution, as demonstrated most clearly by the legislative history of the INA. Prior to 1965, U.S. law required an asylum applicant to demonstrate past physical persecution in order to qualify for protection. But the INA was amended in 1965 to remove the qualifier of "physical" from the term..$^{39}$ Courts have affirmed this change by rejecting a requirement to demonstrate physical harm, and more generally, finding that persecution is a "broader concept than threats to "life or freedom." 40 In the case of In re T-Z-, the BIA found that to constitute persecution, "the harm or suffering need not [only] be physical, but may take other forms, such as the deliberate imposition of severe economic disadvantage or the deprivation of liberty, food, housing, employment or other essentials of life." ${ }^{\prime 41}$ In fact, even psychological harm and emotional trauma have been held

2000)). See also Beskovic v. Gonzales, 467 F.3d 223, 225 (2d Cir. 2006) (“'persecution' in the asylum context means that the mistreatment must rise above mere harassment ..."); Nelson v. INS, 232 F.3d 258, 263 (1st Cir. 2000); Mikhailevitch v. INS, 146 F.3d 384, 390 (6th Cir. 1998) ('“persecution' . . requires more than a few isolated incidents of verbal harassment or intimidation ..."); Bastanipour v. INS, 980 F.2d 1129, 1133 (7th Cir. 1992) (distinguishing persecution "from mere discrimination or harassment").

36 Zakirov v. Ashcroft, 384 F.3d 541, 546 (8th Cir. 2004).

37 See, e.g., Borovsky v. Holder, 612 F.3d 917 (7th Cir. 2010) (denying asylum because the applicant was unable to demonstrate that the Ukrainian government condoned or was unable to combat anti-Semitism); Wakkary v. Holder, 558 F.3d 1049, 1060-62 (9th Cir. 2009) (requiring proof of a "pattern or practice" in order for discrimination to rise to the level of persecution); Berte v. Asheroft, 396 F.3d 993 (8th Cir. 2005) (holding that barriers to the exercise of citizenship rights, such as challenges in obtaining required ID documents, are a form of discrimination that do not rise to the level of persecution).

38 Rife v. Ashcroft, 374 F.3d 606, 612 (8th Cir. 2004). See also Shoaira v. Ashcroft, 377 F.3d 837, 844 (8th Cir. 2004) (quoting Regalado-Garcia v. INS, 305 F.3d 784, 787 (8th Cir. 2002)) (persecution is "the infliction or threat of death, torture, or injury to one's person or freedom"); Bace v. Ashcroft, 352 F.3d 1133, 1137 (7th Cir. 2003).

39 Immigration Nationality Act, Amendments, Pub. L. No. 89-236, § $11(f), 79$ Stat. 918 (1965).

40 INS v. Stevic, 467 U.S. 407, 428 n.22 (1984).

4124 I. \& N. Dec. 163, 171 (B.I.A. 2007) (emphasis added, bracketed text original). See also Chen v. Gonzales, 470 F.3d 1131, 1135 (5th Cir. 2006) (quoting Abdel-Masieh v. INS, 73 F.3d 579, 583 (5th Cir. 1996)). 
to constitute persecution in certain situations. ${ }^{42}$

Violation of an individual's human rights or fundamental beliefs can also constitute persecution. In Fatin v. INS, the Third Circuit considered the case of an Iranian woman whose feminist beliefs led her to refuse to conform to gender-specific laws (specifically, refusing to wear the Chador, a traditional Islamic veil). ${ }^{43}$ The court concluded that "persecution is broad enough to include governmental measures that compel an individual to engage in conduct that is not physically painful or harmful but is abhorrent to that individual's deepest beliefs" and that "such conduct might be regarded as a form of 'torture' . . . falling within the Board's description of persecution in Acosta." ${ }^{\prime 44}$ The materials used in USCIS's Asylum Officer Basic Training Course echo the Fatin ruling, stating that "certain violations of 'core' or 'fundamental' human rights, as prohibited by customary international law, may constitute harm amounting to persecution." 45

When addressing forced marriage, U.S. federal agencies charged with immigration functions and duties have interpreted cases such as In re T-Z- and Fatin to arrive at the conclusion that the practice is a harm that is "serious enough to be persecution." 46 The 2001 Gender Guidelines for Overseas Refugee Processing ${ }^{47}$ recognize that forced marriage and other forms of gender-based violence are not distinct from other, more traditional, forms of persecution and instruct that an evaluation of whether such harms constitute persecution should be made using "the same factors and guidance that an Immigration Officer uses

42 See In re A-K-, 24 I. \& N. Dec. 275, 278 (B.I.A. 2007) ("We recognize that there may also be cases where a person persecutes someone close to an applicant, such as a spouse, parent, child or other relative, with the intended purpose of causing emotional harm to the applicant, but does not directly harm the applicant himself."); Mashiri v. Ashcroft, 383 F.3d 1112 (9th Cir. 2004).

4312 F.3d 1233 (3d Cir. 1993).

44 Id. at 1242.

45 AOBTC, supra note 24, Lesson 1: Definition of Refugee; Definition of Persecution; Eligibility Based on Past Persecution at 22, available at http://www.uscis.gov/sites/default/files/USCIS/Humanitarian/ Refugees $\% 20 \% 26 \% 20$ Asylum/Asylum/AOBTC\%20Lesson\%20Plans/Definition-Refugee-PersecutionEligibiity-3l aug 10.pdf [http://perma.cc/6J73-9PFK].

46 Immigration \& Naturalization Servs., Gender Guidelines for Overseas Refugee Processing 5 (2001).

47 The 2001 Gender Guidelines, supra note 46 , were the product of a Congressionally mandated inter-agency task force that included representatives from the U.S. Department of State, U.S. Department of Justice, and other federal agencies. The Guidelines detail eligibility criteria for women seeking refugee status, including both substantive and procedural aspects of gender-related refugee issues. 
to assess the level of harm in any refugee case." ${ }^{" 48}$ Similarly, the Asylum Officer Basic Training Course materials state that "where marriage is actually forced on an applicant against the applicant's will, it may constitute persecution." 49 In its foundational document, the Foreign Affairs Manual, the U.S. Department of State plainly asserts that "[t]he Department considers a forced marriage to be a violation of basic human rights." ${ }^{50}$ Although these administrative agency determinations are not binding on federal courts, they should be considered highly persuasive. And yet, despite these relevant agencies' acceptance of forced marriage as a persecutory act, courts adjudicating such claims nearly universally refuse to recognize forced marriage as persecution.

An analysis of courts' treatment of persecution in the context of forced marriage reveals several troubling patterns. Certain aspects of the law are clear, such as the fact that arranged marriage-one in which neither party is compelled to enter the union-does not constitute persecution. ${ }^{51}$ However, a court's refusal to recognize that forced marriage is persecution frequently occurs as a result of its improper conflation of forced and arranged marriage. For example, in Matter of $A-T$-, in a section of its opinion entitled "Arranged Marriage," the BIA dismissed the applicant's fear of forced marriage, stating:

It is understandable that the respondent, an educated young woman, would prefer to choose her own spouse rather than acquiesce to pressure from her family to marry someone she does not love and with whom she expects to be unhappy. The respondent has also expressed valid concerns about possible birth defects resulting from a union with her first cousin. While we do not discount the respondent's concerns, we do not see how the reluctant acceptance of family tradition over personal preference can form the basis

48 Immigration \& Naturalization Servs., Gender Guidelines for Overseas Refugee Processing 5 (2001).

49 AOBTC, supra note 24, Lesson 26 at 23.

50 U.S. Dep't. State. Foreign Affairs Manual, 7 FAM 1459(a) (2005).

51 Mansour v. Ashcroft, 390 F.3d 667, 680 (9th Cir. 2004) (stating that arranged marriage, "while unfortunate and deplorable, may not constitute persecution if imposed on an adult ..."). 


\section{for a withholding of removal ${ }^{52}$ claim. $^{53}$}

Citing Mansour v. Ashcrof $t^{54}$ to support the proposition that arranged marriage does not constitute persecution and noting that A-T- and the man her family chose for her to marry were of similar ages and backgrounds, the Board concluded that the "arranged marriage" would not constitute persecution. The BIA's labeling of A-T-'s marriage as arranged, rather than as forced, is puzzling, in part because the court acknowledges the presence of family compulsion for A-T- to marry against her will. The categorization is also strange because the court seemingly ignores its own list of valid reasons for why A-T- objected to her impending marriage, and dismisses as a "personal preference" the obvious harm of a lifetime of unhappiness created by a loveless marriage entered into under duress.

However, even when courts recognize that a case is clearly situated in the forced marriage context, the harms are regularly found to not be sufficiently serious so as to constitute persecution. Administrative agencies have recognized that forced marriage constitutes persecution and courts have plainly stated that forcing a woman to engage in an act that (like forced marriage) is abhorrent to her "deepest beliefs" 55 and deprives her of an "essential" 56 aspect of life, constitutes persecution. However, despite this precedent, courts have routinely found that efforts to marry a woman against her will constituted harassment rather than persecution, even when accompanied by acts such as threats, detention and beatings

52 Because A-T- did not file her application for asylum within one year of entering the United States and the lower court determined that she did not qualify for any of the exceptions to this one year filing deadline, the Board of Immigration Appeals found that she was ineligible for asylum and considered her case for withholding of removal (where the one year filing deadline does not apply). In re A-T-, 24 I. \& N. Dec. 296, 301-32 (B.I.A. 2007), judgment vacated and remanded sub nom. Matter of A-T-, 24 I. \& N. Dec. 617 (B.I.A. 2008). The standard for withholding of removal—a clear probability of persecution-is more stringent than asylum's "well-founded fear," but while a grant of asylum is discretionary, withholding is mandatory under U.S. treaty obligations if an applicant can show that her "life or freedom would be threatened ... because of [her] race, religion, nationality, membership in a particular social group, or political opinion" in her home country. Immigration and Nationality Act $\$ 241$ (b)(3)(A), 8 U.S.C.A. $\$ 1231$ (b)(3)(A)(West 2013). When eligibility for withholding is established, an immigration judge must issue an order of removal, which is then withheld, or not executed. See Matter of I-S- \& C-S-, 24 I. \& N. Dec. 432 (B.I.A. 2008). A withholding status therefore does not confer the same benefits as asylum, such as, most significantly, the rights to apply for lawful permanent resident status and to petition for qualifying family members.

53 In re A-T-, 24 I. \& N. Dec. at 302-03.

54 See supra note 51.

55 Fatin v. INS, 12 F.3d 1233, 1242 (3d Cir. 1993).

56 In re T-Z-, 24 I. \& N. Dec. 163, 171 (B.I.A. 2007). 
of family members and property destruction. ${ }^{57}$

For example, in Li Rong Zhang v. Att'y Gen. of U.S., the court held that "a marriage proposal, even by someone you detest, does not rise to the level of persecution," ignoring the fact that the proposals were made by the head of the applicant's village--someone who exercised great power in her community - and accompanied by threats to jail her if she did not comply. ${ }^{58}$ Similarly, in Shao Lan Yan v. Holder, the applicant's rejection of the village chief's nephew's proposal resulted in her home being vandalized and her brother being physically assaulted; the court found that these actions did not constitute persecution. ${ }^{59}$ Finally, and perhaps most strikingly, in Xiu Xia Huang v: Att'y Gen. of U.S., the detention of the applicant's father, the destruction of her family's crops, and the beating of the applicant's boyfriend were considered "mere harassment." ${ }^{60}$ The court appeared to rely on the absence of physical harm to the applicant herself in making its determination that persecution did not exist, misapplying the law ${ }^{61}$ as well as ignoring the facts when it stated that "there is no evidence that anyone in China is interested in harming her."62

One of the most concerning aspects of these cases is that harms that would likely be deemed to rise to the level of persecution in a non-forced marriage context are categorically dismissed because they occurred in a family setting. ${ }^{63}$ But even if the courts recognized that these ancillary harms constituted persecution, the fact that the focus of their analysis rests solely on the harms surrounding forced marriage, as opposed to the persecution inherent in forced marriage itself, remains problematic. For example, in Shao Lan Yan, the court noted that the applicant "feared that she would be "forced to marry a person [she] do[es] not love

57 See, e.g., Li Rong Zhang v. Att'y Gen. of U.S., 494 F. App'x 255 (3d Cir. 2012); Shao Lan Yan v. Holder, 489 F. App'x 733 (4th Cir. 2012); Xiu Xia Huang v. Att'y Gen. of U.S., 286 F. App'x 604 (11th Cir. 2008). See also Yan Hua Lin v. Gonzales, 246 F. App'x 746, 748 (2d Cir. 2007).

58494 F. App'x at 256.

$59 \quad 489$ F. App'x at 733-34.

60286 F. App'x at $605-06$.

61 See supra Part I.B.1.

62286 F. App'x at 605.

63 This result may be due in part to what is described by international law scholars as the public-private distinction, wherein, for example, a violation such as rape that occurs in the public sphere of "politics, government and the state" is considered a human rights violation, unlike a rape that occurs in the privacy of one's home or within one's family. Hilary Charlesworth, Feminist Methods in International Law, 93 AM. J. INT'L L. 379, 382 (1999); see also Jaya Ramji-Nogales, Questioning Hierarchies of Harm: Women, Forced Migration, and International Criminal Law, 11 INT'L CRIM. L. Rev. 463 (2011). 
and do[es] not wish to marry," but said nothing more about this critical fact ${ }^{64}$ Like the BIA in Matter of A-T-, the Fourth Circuit seemed to discount the harm of Ms. Yan being forced to spend her life with a man she did not care for or choose to marry, indicating that the court did not consider the act of a forced marriage itself to be persecution, or even problematic.

Admittedly, "the concept of persecution does not encompass all treatment that our society regards as unfair, unjust, or even unlawful or unconstitutional." ${ }^{\circ 5}$ Similarly, not everything that is prohibited by domestic or international law does, or should, constitute persecution in the asylum context. But as Parts II and III below will discuss, given the history and reverential treatment of marriage by courts in the international and domestic constitutional context - the recognition that marriage is a uniquely special, even sacred, relationship that should never be entered into absent free and full consent-federal courts and the BIA have erred in not treating forced marriage as a persecutory act under asylum law.

\section{Nexus}

Even if the core question of whether forced marriage constitutes persecution were resolved, a discussion of the issue would be incomplete without also addressing "nexus," an area of asylum law that is inextricably related to persecution. Nexus is a complex concept, and as will be demonstrated below, courts have struggled with both identifying and defining nexus in forced marriage cases, often conflating their analysis of nexus with their inquiry into persecution and even whether the feared persecution was perpetrated by a governmental or private actor. Although this Article contains a separate and discrete discussion of nexus, it must be noted that courts' examinations of the issue are not as readily isolated.

As a brief introduction to the topic, "nexus" is the requirement that an asylum seeker demonstrate that the persecution she suffered or fears is "on account of" one of five grounds enumerated in the refugee definition: race, religion, nationality, membership in a particular social group, or political opinion. ${ }^{66}$ To establish nexus, the applicant must provide evidence that the persecutor was or is motivated to act because the victim possesses or is believed to possess the protected characteristic ${ }^{67}$ An enumerated ground must be "at least one central

64 Shao Lan Yan v. Holder, 489 F. App'x 733, 734 (4th Cir. 2012)

65 Camara v. Att'y Gen. of U.S., 580 F.3d 196, 202 (3d Cir. 2009). See also Kho v. Keisler, 505 F.3d 50, 57

(1st Cir. 2007) (quoting Sharari v. Gonzales, 407 F.3d 467, 474 (1st Cir. 2005)); Lumaj v. Gonzales, 462 F.3d 574, 577 (6th Cir. 2006) (quoting Fatin v. INS, 12 F.3d 1233, 1240 (3d Cir. 1993)).

66 Immigration and Nationality Act $\S 208(b)(1)(B)(i), 8$ U.S.C.A. $\S 1158(b)(1)(B)(i)$ (West 2013).

67 See INS v. Elias-Zacarias, 502 U.S. 478, 482-84 (1992). 
reason" ${ }^{\prime 68}$ for the persecutor's actions; however, it does not have to be the sole reason for the persecution, as persecutors may have "mixed-motives" for perpetrating harms. ${ }^{69}$

A forced marriage asylum claim, like many gender-based claims, is likely to base a nexus argument in the "membership in a particular social group" category, which is the most nuanced and complex of the five asylum grounds. ${ }^{70}$ The elements of a particular social group in a forced marriage claim will vary based on the specific facts of the case and circumstances of the applicant, but characteristics such as nationality, ethnicity, tribal affiliation, age, religion, family membership, education level, opposition to abuse, or transgression of social/cultural norms are likely to be included.?! It should be noted, however,

\section{U.S.C.A. § $1158($ b)(1)(B)(i) (West 2013).}

69 The mixed-motive theory posits that a persecutor may be motivated to harm a victim for more than one reason-some related to a protected ground but others perhaps unrelated-and that there is no requirement that only the former exist. In In re J-B-N-\&S-M-, the BIA examined the legislative history surrounding the motivation requirement and found that the fact that the law's requirement that the protected characteristic must be "at least one central reason" for persecution rather than "the central reason" for persecution logically necessitates adoption and acceptance of mixed-motive cases. 24 I. \& N. Dec. 208, 213 (B.I.A. 2007) (emphasis added).

70 A "particular social group" has been defined in Matter of Acosta as comprising individuals who share "a common, immutable characteristic" that either cannot be changed or is so fundamental to the individuals" identities or consciences that they should not be required to change them. 19 I. \& N. Dec. 211,212 (B.I.A. 1985), overruled on other grounds by Matter of Mogharrabi, 19 I. \& N. Dec. 439 (B.1.A. 1987). This shared characteristic "might be an innate one such as sex, color, or kinship ties, or in some circumstances it might be a shared past experience such as former military leadership or land ownership." Acosta, 19 I. \& N. Dec. at 233. Recent changes to social group jurisprudence also require that the defined group possess "social distinction," or proof that the group is perceived as such in the society in question. Matter of M-E-V-G-, 26 I. \& N. Dec. 227 (B.I.A. 2014); Matter of W-G-R-, 26 I. \& N. Dec. 227 (B.I.A. 2014) (this new standard replaces the prior requirement to establish "social visibility" that was articulated in Matter of C-A-, 23 I. \& N. Dec. 951 (B.I.A. 2006), which, according to the court in $M-E-V-G$ - and $W-G-R$-, had improperly been understood as a requirement of "ocular visibility."). A particular social group must also be sufficiently "particular." See Matter of A-M-E- \& J-G-U-, 24 I. \& N. Dec. 69 (B.I.A. 2007); Matter of S-E-G-, 24 I. \& N. Dec. 579 (B.I.A. 2008) (defining particularity as "whether the proposed group can accurately be described in a manner sufficiently distinct that the group would be recognized, in the society in question, as a discrete class of persons.").

71 See, e.g., Sarhan v. Holder, 658 F.3d 649, 655 (7th Cir. 2011) ("women in Jordan who have (allegedly) flouted repressive moral norms, and thus who face a high risk of honor killing"); Manani v. Filip, 552 F.3d 894, 901 (8th Cir. 2009) ("Kenyan widows opposed to wife inheritance and to the performance of FGM on their daughters"); Himanje v. Gonzales, 184 F.App'x. 105, 107 (2d Cir. 2006) ("woman [sic] from the Tongo tribe of Zambia who have been sold into marriage"); Fiadjoe v. Att'y Gen. of U.S., 411 F.3d 135, 137, 168 (3d Cir. 2005) ("unmarried women over age 25 in Ghana" or "Ghanaian women from the Ewe tribe in the Volta Region who have been subjected to or face being subjected to the practice of Trokosi and who oppose this practice"); Yadegar-Sargis v. I.N.S., 297 F.3d 596, 603 (7th Cir. 2002) ("Christian women in Iran who do not wish to 
that while such distinguishing and narrowing characteristics are typically advanced in gender-based asylum claims, a social group based on gender alone is arguably sufficient, as sex is listed as one of Acosta's immutable characteristics and both the Eighth and Ninth Circuits have opined on limited social groups based on gender alone. ${ }^{72}$

Nevertheless, lack of nexus has proven a basis for courts to systematically deny asylum to victims of forced marriage. Even when applicants argue that the persecutors had mixed-motives for persecution, many courts deny claims by classifying the harm as being perpetrated for "personal" reasons as opposed to punishing the victims for possessing a protected characteristic. An archetypal example is the case of Ying Lin v. U.S. Attorney General, where the court considered the case of a young woman from China whose parents sold her to a man nicknamed Brother Nine in order to have their debts forgiven. ${ }^{73}$ After Brother Nine, a casino owner and police officer, attempted to rape Ms. Lin prior to their wedding, she reported his actions to the authorities. ${ }^{74}$ They not only refused to assist her, but advised her that Brother Nine would be a good person to marry because he was "important and wealthy." 75 The BIA, in upholding the Immigration Judge's denial, rejected the argument that Ms. Lin was targeted for harm due to her membership in the particular social group of "unmarried women in a lower social class or in a rural area." "76 Instead, the court held that she was being forced into marriage "for no reason other than repayment of her mother's gambling debt," which was "'entirely a personal matter between her, her family and ... Brother Nine." "'

adhere to the Islamic female dress code"); Abankwah v. I.N.S., 185 F.3d 18, 21 (2d Cir. 1999) ("women of the Nkumssa tribe who did not remain virgins until marriage"); In re Kasinga, 21 I. \& N. Dec. 357, 358 (B.I.A. 1996) ("young women of the Tchamba-Kunsuntu Tribe who have not had FGM, as practiced by that tribe and who oppose the practice").

72 See, e.g., Perdomo v. Holder, 611 F.3d 662, 667 (9th Cir. 2010) ("Thus, we clearly acknowledged that women in a particular country, regardless of ethnicity or clan membership, could form a particular social group."); Hassan v. Gonzales, 484 F.3d 513, 518 (8th Cir. 2007) (finding "Somali females" to be a cognizable particular social group); Mohammed v. Gonzales, 400 F.3d 785, 800 (9th Cir. 2005) ("although we have not previously expressly recognized females as a social group, the recognition that girls or women or a particular clan or nationality (or even in some circumstances women in general) may constitute a social group is simply a logical application of our law.") (internal citation omitted).

73319 F. App'x 777 (11th Cir. 2009).

74 ld. at 779.

75 Id.

76 Id.

77 Id. at 779-81. 
This reasoning is plainly flawed. Although the persecutor may have targeted Ms. Lin both because of his personal desire to secure money from her family and because he recognized Ms. Lin as vulnerable due to her poverty, marital status, and isolation - which would make this case fall squarely in the mixed-motive category-the court focused only on the former explanation and declined to consider that nexus was established due to her membership in a particular social group. Other courts have found efforts to force individuals into marriage to be "the aberrational act of a corrupt official," $"$ and therefore not "on account of" their membership in a particular social group, or have denied relief on religious grounds because objections to forced marriage were seen as based on "personal preference" rather than religious conviction. ${ }^{79}$ Still others have simply asserted that nexus did not exist without much explanation or analysis. ${ }^{80}$

Like their analysis of persecution, courts' treatment of nexus in the forced marriage context is troubling. The United States grants asylum to women whose home countries are unwilling to protect them from gender-based harms such as domestic violence or FGM because these problems are considered to be private "family matter[s]." federal courts' assertions that the problem of forced marriage is of a personal nature that cannot be remedied by U.S. law is ironically similar to the claims of these foreign law enforcement officials who refuse to intervene and are therefore considered by the United States to have failed in their duty to protect their own citizens.

Moreover, the notion that a family's participation in persecution somehow vitiates nexus has no basis in asylum law. For example, to use a scenario common in forced marriage cases that turn on nexus, when one considers the fact that a persecutor may have mixed-motives for his actions, a family's sale of a daughter to satisfy a debt does not diminish the

78 Lizhu Chen v. Bureau of Citizenship \& Immigration Servs., 238 F. App'x 669, 670 (2d Cir. 2007). See also Xuefang He v. Holder, $502 \mathrm{~F}$. App'x 430, 435 (6th Cir. 2012) (denying asylum because the motives of the police chief who agreed to release a Christian woman from detention only if she married his son "were entirely personal; the director used the force of his office to make marital arrangements because his son could not find a spouse on his own.").

79 Syed v. Mukasey, 288 F. App'x 273, 275 (7th Cir. 2008) (accepting the immigration judge's finding that Syed's opposition to arranged marriage was a personal preference rather than religious conviction).

80 See, e.g., Mei Y. Liu v. Holder, 492 F. App'x 196, 198 (2d Cir. 2012); Feng Ming Lin v. Holder, 339 F. App'x 102, 103 (2d Cir. 2009); Lin v. Gonzales, 148 F. App'x 38, 39 (2d Cir. 2005).

81 See, e.g., Ngengwe v. Mukasey, 543 F.3d 1029, 1032 (8th Cir. 2008); In re R-A-, 22 I. \& N. Dec. 906 (B.I.A. 1999), vacated, In re R-A-, 22 I. \& N. Dec. 906 (Op. Att'y Gen. 2001), remanded, 23 I. \& N. Dec. 694 (Op. Att'y Gen. 2005), stay lifted, 24 I. \& N. Dec. 629 (Op. Att'y Gen. 2008), asylum granted in an unpublished Immigration Judge opinion on December 10, 2009. 
existence of a coexisting basis for the "purchaser's" imposition of harm. A man may in fact be receiving a bride as payment, but he is often able to force her to marry him due to other characteristics she possesses-ranging from her gender, age, level of education, financial standing and even the lack of protection from her family-all of which can be "common immutable characteristics" ${ }^{82}$ that comprise a particular social group. ${ }^{83}$ In such cases, family participation does not destroy nexus, it creates it.

Denial of claims because persecution occurred at the hands of public officials who acted outside of their official capacities similarly demonstrates the disparity of treatment of forced marriage-based asylum claims. Imagine the case of a police chief, who, acting outside his sanctioned authority, used his status to cause harm to a religious minority that he found personally objectionable. Would that fact pattern not raise a classic, and categorically viable, asylum claim? In fact, courts have recognized precisely such claims, noting that "[a] public official who uses his office for personal motivations can nonetheless be acting in his official capacity." ${ }^{84}$ Yet it appears that when officers misuse their power to procure wives for themselves or other family members, the gendered nature of the persecution destroys nexus in the eyes of the court. ${ }^{85}$

82 Matter of Acosta, 19 I. \& N. Dec. 211, 212 (B.I.A. 1985), overruled on other grounds by Matter of Mogharrabi, 19 I. \& N. Dec. 439 (B.I.A. 1987).

83 For example, the particular social group of "unmarried women in a lower social class or in a rural area" proposed in Ying Lin v. U.S. Att'y Gen., 319 F. App'x 777, 779 (11 th Cir. 2009).

84 Marmorato v. Holder, 376 F. App'x. 380, 385 (5th Cir. 2010). Marmorato is a case involving a claim for relief under the Convention Against Torture (CAT). To qualify for CAT protection, the torture feared must be carried out by the applicant's government or by someone acting with the acquiescence of the government-a "state action" requirement-and the court in Marmorato addressed whether the public officials in question would be acting in their personal or official capacities in persecuting the applicant. The analysis in Marmorato remains relevant here, however, as it highlights the persistent confusion surrounding the nexus requirement in asylum cases, which is often conflated with the requirement to demonstrate that the government either perpetrated or was unwilling or unable to protect the applicant from harm. See supra note 30. The court in Lizhu Chen used the lack of state action, the stated "aberrational act of a corrupt official," to conclude that nexus did not exist in that forced marriage case. Lizhu Chen v. Bureau of Citizenship \& Immigration Servs., $238 \mathrm{~F}$. App'x 669, 670 (2d Cir. 2007). Similarly, in Xuefang Hev. Holder, under a section entitled "The IJ's Finding that the Level of Harm Did Not Rise to an Extreme Level of Persecution," the court conflated its analysis of persecution, nexus, and mixed-motive theory with its inquiry as to whether the police chief who was forcing a woman to marry his son was acting in his personal or official capacity. 502 F. App'x 430, 435 (6th Cir. 2012).

85 See, e.g., Lizhu Chen, 238 F. App'x at 670; Xuefang He, 502 F. App'x at 435. 


\section{The Impact of Gao v. Gonzales}

Only one published federal case directly addresses the question of whether forced marriage constitutes persecution and ultimately grants asylum protection to a victim of the practice-Gao v. Gonzales. ${ }^{86}$ Ms. Gao, a young woman from China, was sold into marriage by her parents in order to satisfy family debts. ${ }^{87}$ Initially assenting to the marriage under significant pressure, she later attempted to break off the engagement ${ }^{88}$ As in many of the cases discussed in Section I.B.2 above, the Immigration Judge denied her claim due to lack of nexus, finding that Ms. Gao's predicament was "simply 'a dispute between two families." ${ }^{89}$ On appeal, the Second Circuit rejected this reasoning, stating that the Immigration Judge's finding that a financial arrangement between families precluded a discriminatory motive was "antithetical to the very notion of individual rights on which asylum law is based." ${ }^{90}$ Ultimately, the court held that "lifelong, involuntary marriage" constitutes persecution (a fact that it stated the government "appear[ed] to concede"92) and granted Ms. Gao asylum based on her membership in the particular social group of "women who have been sold into marriage (whether or not that marriage has yet taken place) and who live in a part of China where forced marriages are considered valid and enforceable. ${ }^{\prime 93}$

Although the pronouncements regarding asylum protection for victims of forced marriage in Gao were clear, the case was overruled in 2007 by the Supreme Court on procedural grounds, ${ }^{94}$ leaving a jurisprudential vacuum and creating uncertainty for applicants and their advocates. ${ }^{95}$ In the years after Gao, there have been no published decisions rec-

86440 F.3d 62 (2d Cir. 2006).

87 Id. at 64 .

88 Id.

89 Id. at 65 .

90 Id. at 70 .

91 Id.

92 Id. at 66.

93 Id. at 70.

94 Keisler v. Hong Yin Gao, 552 U.S. 801 (2007).

95 For example, in Shao Lan Yan v. Holder, the applicant sought an appeal of the denial of her asylum claim based on forced marriage and the Board of Immigration Appeals remanded her case to the Immigration Judge for reconsideration in light of the ruling in Gao. However, after Gao was vacated, the Immigration Judge declined to reconsider its earlier ruling and adopted and reissued in whole its prior denial. In 
ognizing forced marriage itself as a form of persecution that can be a basis for asylum. In 2008, the Eighth Circuit heard Ngengwe v. Mukasey, in which a widow from Cameroon sought asylum after her deceased husband's family threatened to kill her and take away her children if she did not marry her brother-in-law. ${ }^{96}$ The court conducted a thorough social group analysis and determined that the BIA erred in rejecting the particular social group of "Cameroonian widows" posited by Ms. Ngengwe. In doing so, and in evaluating whether the harm suffered rose to the level of persecution, the court referenced Gao and stated that "[t]he question of whether forced marriage constitutes persecution is an open issue."

At least one court has expressed support for forced marriage as a basis for asylum in the post-Gao world. The Sixth Circuit in Bi Xia Qu v. Holder found nexus between persecution and the applicant's membership in the particular social group of "women in China who have been subjected to forced marriage and involuntary servitude." 98 In remanding the case to the Board of Immigration Appeals after that court's initial denial of the claim, the federal appeals court criticized the fact that the "BIA seemed to view the entire matter as simply a debt collection dispute." ${ }^{.99}$ The Sixth Circuit also asserted that a mixed-motive likely existed because it was "clear that [the man who kidnapped, attempted to rape, threatened, and sought to marry Qu] targeted [her] both to secure the repayment of his loan from Qu's father and because she was a woman whom he could force into marriage in a place where forced marriages are accepted." 100 "[I]f there is a nexus between the persecution and the membership in a particular social group," the court reasoned, "the simultaneous existence of a personal dispute does not eliminate that nexus." 101

Although the Sixth Circuit rendered the correct decision with respect to nexus in $B i$ $X i a Q u$, its value is limited by the narrow approach to persecution. The court considered Ms. Qu's forced marriage a persecutory act only because she suffered what it considered

considering and upholding the validity of this procedural history, the Fourth Circuit Court of Appeals noted that while the applicant "quibble[d]" over the basis of the Supreme Court's actions, "the fact remains that Gao has been vacated." 489 F. App'x 733, 738 (4th Cir. 2012) (emphasis in original).

96543 F.3d 1029, 1033 (8th Cir. 2008).

97 Id. at 1036.

98 618 F.3d 602, 607 (6th Cir. 2010).

99 ld. at 609.

100 Id. at 608 (emphasis in original).

101 ld. 
to be "a severe form of the practice,"102 as opposed to "cases in which women fear being forced into marriage ... because they have been threatened by potential perpetrators and it is a common practice in their country." 103 In making this determination, the court not only misapplies the facts, as the "severity" of the forced marriage in Bi Xia Qu does not differ significantly from many of the cases described elsewhere in this Article where asylum was denied due to lack of persecution, but once again seems to disregard any harm inherent in forced marriage itself.

Although the Sixth Circuit has demonstrated some potential progress, other courts have strictly interpreted Gao. For example, the Seventh Circuit held in Xiu Yun Chen v. Gonzales that a young woman who fled to the United States to avoid a forced marriage to the son of a local official "cannot belong to the social group defined in Gao, which explicitly limited its social-group definition to the facts of the case, because she was not sold into marriage." 104

Ultimately, courts' treatment of forced marriage in asylum cases is flawed, both in the judges' inconsistency and their disparate treatment of claims involving this form of gender-based violence. Whether denied due to a lack of differentiation between forced marriage and arranged marriage, a dismissive attitude towards the injury involved in marrying against one's will, or the inability to acknowledge the existence of persecution in a familial context, women making these types of claims are unduly, summarily, and unjustly denied relief.

This outcome is improper not only because it results from a flawed analysis of courts' own asylum jurisprudence, but also because it diverges from countless other legal interpretations that recognize marriage as an institution worthy of great reverence and protection, and accordingly, forced marriage as a violation of human rights. As demonstrated above and as will be shown in Parts II and III below, the courts' analyses of persecution in the asylum context are at odds with the interpretations of administrative agencies such as USCIS and the Department of State as well as both international and domestic jurisprudence regarding marriage and its essential element of consent.

102 Id. at 607 ("[S]he was kidnapped for two weeks until she escaped, her perpetrator attempted to rape her, and he threatened to send her to prison if she did not marry him.").

103 Id.

104 Xiu Yun Chen v. Gonzales, 229 F. App'x 413, 415 (7th Cir. 2007) (internal citation omitted). This statement is of particular concern because the court in Gao specifically stated that the fact that its "definition of Gao's social group is tailored to the facts of this case and does not reflect any outer limit of cognizable social groups." Gao v. Gonzales, 440 F.3d 62, 70 n.6 (2d Cir. 2006), cert. granted, judgment vacated sub nom. Keisler v. Hong Yin Gao, 552 U.S. 801 (2007). 


\section{The Evolution of United States Law Regarding Access to Marriage}

\section{A. Moving Towards a View of Marriage as an Egalitarian and Emotionally-Focused Institution}

The understanding of the institution of marriage that exists in the United States today is dramatically different from the view of the general populace in the nation's earlier years. The common law doctrine of coverture that regulated marital relationships in the American colonial period codified the subordination of women in marriage, as they effectively became the property of their husbands. ${ }^{105}$ Women's inequality in marriage also extended to the area of immigration and naturalization through laws like the Expatriation Act of 1907, which divested women of their U.S. citizenship if they married noncitizens. ${ }^{106}$

As law and culture advanced, coverture slowly began to unravel, signaling an important shift in societal conceptions of marriage. In a case affirming the conviction of a husband who attempted to murder his wife, a Kentucky appellate court described a husband's ability to "compel his wife to obey his wishes, by force if necessary" as "a relic of barbarism that has no place in an enlightened civilization." 107 Other advances such as the women's suffrage movement, the rise in women's employment, and women's sexual liberation all led to

105 The law of coverture stated that "[b]y marriage, the husband and wife are one person in law: that is, the very being or legal existence of the woman is suspended during the marriage, or at least is incorporated and consolidated into that of the husband; under whose wing, protection, and cover, she performs everything. . . . The husband also ... might give his wife moderate correction." I William Blackstone, Commentaries *430-33. Under coverture, "a woman's legal identity all but evaporated into that of her husband" and men were explicitly given the right to commit spousal violence with impunity. Goodridge v. Dep't. of Pub. Health, 798 N.E.2d 941, 967 (Mass. 2003) (citing C.P. Kindregan, JR., \& M.L. InKer, Family LaW and Practice $\S$ $1.9,1.10(3 \mathrm{~d}$ ed. 2002)).

106 Expatriation Act, ch. 2534, § 3, 34 Stat. 1228, 1228-29 (1907) (repealed 1940). The Act was predicated on the reasoning that a wife automatically assumed the nationality of her husband, and in affirming its legality, the U.S. Supreme Court expressed its support for the idea that marriage served "to merge [the] identit[ies of a man and his wife], and give dominance to the husband." Mackenzie v. Hare, 239 U.S. 299, 311 (1915). For a fascinating history and examination of the Expatriation Act, including the circumstances of its eventual repeal, see Leti Volpp, Divesting Citizenship: On Asian American History and the Loss of Citizenship Through Marriage, 53 UCLA L. Rev. 405, 425-31 (2005). Other immigration policies based on coverture, including those relating to quotas and the level of control exercised by a petitioning fiancé or spouse in the family-based immigration system, perpetuated the notion of women's subservience to their husbands. See Janet M. Calvo, Spouse-Based Immigration Laws: The Legacies of Coverture, 28 SAN Diego L. Rev. 593 (1991); Janet Calvo, A Decade of Spouse-Based Immigration Laws: Coverture's Diminishment, but Not Its Demise, 24 N. ILL. U. L. REv. 153 (2004).

107 Carpenter v. Commonwealth, 18 S.W. 9, 10 (Ky. 1892). 
the dismantling of coverture and a move towards the modern view of women as equals both to men and within the marital relationship. No fault divorce, ${ }^{108}$ first adopted in California in $1969^{109}$ and in all states by $1985,{ }^{110}$ ensured that women could no longer be forced to remain married against their will. Other divorce reforms that followed-including changes in "child custody, child support, alimony, and the division of marital assets"-infused gender neutrality and equality into the institution of marriage."' And within the intact marriage, eradication of the marital rape exemption signaled the end of the concept of a wife as the legal property of her husband. ${ }^{112}$

These vast expansions of rights led to a shift from the idea of marriage as an inequitable and pragmatic institution, one based on notions of ownership and contract, to "the rise of companionate marriage," in which women contribute equally to the union and "spouses are expected to satisfy each others' emotional needs." 113 The institution of marriage began to be understood not as a means for men to control women, but as a way for a man and a woman to each select a partner with whom to achieve happiness and self-fulfillment. ${ }^{14}$

Implicit in this modern, egalitarian understanding of marriage was a recognition of the importance of choice and consent in marriage. Currently, all states deem non-consensual marriages invalid and treat such marriages as either void or voidable. ${ }^{115}$ In fact, "so funda-

108 A no-fault divorce is one in which the parties are not required to prove fault or grounds beyond a showing of the irretrievable breakdown of the marriage or irreconcilable differences. DIVORCE, BLACK's Law Dictionary 551 (9th ed. 2009).

109 Cal. Fam. Code $\S \S 2310-13$ (West 2014).

110 See supra note 108.

111 Nancy F. Cott, Public Vows: A History of Marriage and the Nation 205-06 (2000).

112 See New York v. Liberta, 474 N.E.2d 152 (N.Y. 1984).

113 Kerry Abrams \& Peter Brooks, Marriage as a Message: Same-Sex Couples and the Rhetoric of Accidental Procreation, 21 YAle J.L. \& Human. 1, 10 (2009).

114 See, e.g., Vicki Howard, $A$ 'Real Man's Ring': Gender and the Invention of Tradition, $36 \mathrm{~J}$. Soc. HIST. 837,843 (2003) (suggesting that the growth in popularity of engagement rings for men in the 1920 s was because they were a "symbol of commitment and fidelity [that] might have resonated among those dedicated to the new ideal of companionate marriage.").

115 See 55 C.J.S. Marriage $\$ 19$ (citing case law in a variety of states, including Connecticut, Florida, Kentucky, New York, Oklahoma, South Carolina, Texas, and Vermont). See also U.S. Fid. \& Guar. Co. v. Dowdle, 269 S.W. 119, 124-25 (Tex. Civ. App. 1924) ("In the absence of consent, the status of marriage is never created by any government. The law compels no one to assume the matrimonial status. Without assent, no statute or constitution can create this relation. ... Consent is the essence of marriage, without which it 
mental is the principle that there can be no marriage without the consent of the parties," that in its absence "a part of the general common law [states] that in such a situation as this no marriage ever came into existence." 116 Courts have also routinely found that coercive entry into marriage or the entry into marriage under duress vitiates consent. ${ }^{117}$

\section{B. The U.S. Supreme Court Unequivocally Declares Marriage to be a Fundamental Right}

With this backdrop, as early as the 19 th century, the U.S. Supreme Court began to opine about the importance of marriage in American life. In Maynard $v$. Hill, a case analyzing the legality of a legislative divorce, ${ }^{118}$ the Court stated that marriage is "the foundation of the family and society, without which there would be neither civilization nor progress." 119 The Supreme Court validated the notion of the marital union as a deeply personal association, opining that marriage created "the most important relation in life," as it had "more to do with the morals and civilization of a people than any other institution." 20

The Court continued to consider the nature and significance of marriage when it decided Meyer v. Nebraska, a case not involving marriage or family relationships, but rather a school teacher who was charged with instructing a student in the German language, an unlawful act under a state statute. ${ }^{121}$ In Meyer, marriage was listed among several other liberty rights the Court considered to be "fundamental"-freedom of religion, the ability to obtain an education, and childrearing-its inclusion so casual as to demonstrate the

cannot exist.")

116 Davis v. Davis, 175 A. 574,577 (Conn. 1934).

117 In a 1939 case before the Supreme Court of South Carolina, a young man attempted to dissolve his marriage by claiming that he had entered into the union "under duress and upon certain threats made against him" by family members of his pregnant girlfriend and arguing that he had married her because he "anticipated violence in the event [that he] refused." Campbell v. Moore, I S.E.2d 784, 786-87 (S.C. 1939). In its "Conclusions of Law," the court reiterated that "free consent of the parties ... is essential to a valid marriage contract, and a marriage contract is void where either party refuses to give his or her consent and does not acquiesce in the marriage." Id. at 790.

118 A legislative divorce is one in which a marriage is terminated by a statute enacted by the legislature rather than by a court's decree. DIVORCE, BLACK's LAW DictionaRY 550 (9th ed. 2009).

119125 U.S. $190,211(1888)$.

120 Id. at 204.

121262 U.S. 390 (1923). 
obviousness of its presence among other well-established vital personal freedoms. ${ }^{122}$ Significantly, Meyer was the first time the Court introduced the concept of liberty into an analysis of marriage; in applying this framework, the Court reinforced the notion that central to marriage is the ability to enter into the relationship freely and voluntarily (an idea that would be echoed in the Universal Declaration of Human Rights (UDHR) and subsequent treaties as well as in non-asylum domestic jurisprudence for years to come).

Several years after Meyer, the Supreme Court was once again called on to consider the right to marriage, as challenges to the institution arose in multiple contexts. In a series of cases involving the rights of prisoners, the Court affirmed that "prison walls do not form a barrier separating prison inmates from the protections of the Constitution," namely, the right to enter into the same forms of relationships as those who are not incarcerated. ${ }^{123}$ In Skinner v. Oklahoma, the Court struck down the Habitual Criminal Sterilization Act as violative of the Equal Protection Clause. ${ }^{124}$ In so doing, it stated, "we are dealing here with legislation which involves one of the basic civil rights of man. Marriage and procreation are fundamental to the very existence and survival of the race." ${ }^{25}$ In Turner v. Safley, prisoners were held to have a constitutionally protected right to marry because the court recognized marriage as both a fundamental right and a "constitutionally protected ... relationship."126 Through these cases, the Court's conception of marriage continued to evolve, introducing theories of civil rights and equal protection to the existing liberty analysis. However, regardless of the underlying legal reasoning, what became evident in the decisions was that marriage was considered a basic constitutional right and occupied a fundamental and central role in American life.

In another set of cases, the Court undertook a Due Process analysis in considering whether financial restrictions could be placed on the ability to marry or divorce. The first case, Boddie v. Connecticut, held that filing fees for divorce actions violated the rights of

122 Id. at 399-400 (Liberty "denotes not merely freedom from bodily restraint but also the right of the individual . . to engage in any of the common occupations of life, to acquire useful knowledge, to marry, establish a home and bring up children, to worship God according to the dictates of his own conscience, and generally to enjoy those privileges long recognized at common law as essential to the orderly pursuit of happiness by free men.") (emphasis added).

123 Turner v. Safley, 482 U.S. 78, 84 (1987).

124316 U.S. 535 (1942).

125 Id. at 541 .

126482 U.S. at 96. 
indigent individuals who were unable to pay the fees. ${ }^{127}$ The Court based its decision on what was rapidly becoming a truism, that "marriage involves interests of basic importance in our society." 28 In Zablocki v. Redhail, the Court also relied on the Due Process Clause to declare unconstitutional a statute requiring court approval for those under child support obligations to marry. ${ }^{129}$ Because the Court considered "the right to marry [as being] of fundamental importance," it could not be restricted to those with financial means. ${ }^{130}$

The significance of marriage to U.S. jurisprudence and society became further evident when the Court considered the constitutionality of restrictions on birth control and abortion. In striking down a state statute that criminalized the individual use and doctors' prescription of medication for the purpose of preventing conception in Griswold v. Connecticut, the Court made an uncharacteristically poetic statement about the nature of the institution:

Marriage is a coming together for better or for worse, hopefully enduring, and intimate to the degree of being sacred. It is an association that promotes a way of life, not causes; a harmony in living, not political faiths; a bilateral loyalty, not commercial or social projects. Yet it is an association for as noble a purpose as any involved in our prior decisions. ${ }^{31}$

This effusive description showcased the Court's reverential attitude towards the marital relationship. Language that revealed such respect for marriage was perhaps not surprising given prior statements and holdings by the high Court, yet it is worth highlighting how drastically these statements and general attitudes about marriage differ from those articulated by courts in the asylum context. Marriage is venerated by the U.S. Supreme Court, labeled as "sacred" and "noble," yet when immigration and federal courts evaluate the institution, efforts to force a woman into a marriage against her will are not deemed to be harmful or persecutory acts. ${ }^{132}$

127401 U.S. 371 (1971).

128 Id. at 376.

129434 U.S. 374 (1978).

$130 \quad I d$. at 383.

131 Griswold v. Connecticut, 381 U.S. 479, 486 (1965).

132 Professor Kevin Johnson provides great insight into this phenomenon of "differential treatment of citizens and noncitizens [that in turn] serves as a 'magic mirror' revealing how dominant society might treat domestic minorities if legal constraints were abrogated." Kevin R. Johnson, Race, the Immigration Laws, and 
Griswold's holding also provided yet another analytical framework for marriage-privacy. As the Court queried, "[w]ould we allow the police to search the sacred precincts of marital bedrooms for telltale signs of the use of contraceptives? The very idea is repulsive to the notions of privacy surrounding the marital relationship." 133 The concept of privacy was echoed by the Zablocki Court, when it discussed not only marriage itself but the significance of the choice involved in entering into the union and held that "it would make little sense to recognize a right to privacy with respect to other matters of family life and not with respect to the decision to enter the relationship that is the foundation of the family in our society." 134 A similar rationale regarding the privacy and liberty inherent in the marital relationship was also used in Planned Parenthood of Southeastern Pennsylvania v. Casey, in invalidating restrictions on abortion. ${ }^{135}$

The Court issued its perhaps most well-known decision regarding access to marriage in Loving $v$. Virginia, a case that invalidated anti-miscegenation laws and provided the foundation for decades of rulings on marriage equality issues to follow. ${ }^{136}$ In the relatively brief Loving decision, the Court opined that "marriage is one of the "basic civil rights of man,' fundamental to our very existence and survival." 137 Because "the freedom to marry has long been recognized as one of the vital personal rights essential to the orderly pursuit of happiness by free men," the restriction of the "fundamental freedom" to marry based on racial classifications was found to be "subversive of the principle of equality at the heart of the Fourteenth Amendment."138

Whether based on Due Process, privacy, Equal Protection, or liberty grounds, by the time the Court issued its decision in Loving, the idea that the ability to freely choose a spouse is central to one's being was beyond question or reproach. Standing in stark con-

Domestic Race Relations: A "Magic Mirror" into the Heart of Darkness, 73 Ind. L.J. 1111, 1114 (1998).

\section{3}

Griswold, 381 U.S. at $485-86$.

134

Zablocki, 434 U.S. at 386.

135505 U.S. 833, 851 (1992) ("These matters, involving the most intimate and personal choices a person may make in a lifetime, choices central to personal dignity and autonomy, are central to the liberty protected by the Fourteenth Amendment. At the heart of liberty is the right to define one's own concept of existence, of meaning, of the universe, and of the mystery of human life. Beliefs about these matters could not define the attributes of personhood were they formed under compulsion of the State.").

388 U.S. 1 (1967). 
trast, the outlier, was asylum law, where despite case law affirming that violations of one's "deepest beliefs" constituted persecution, ${ }^{139}$ federal and immigration courts declined to consider forced entry into marriage a persecutory act.

\section{State Supreme Court Cases Granting Same-Sex Couples the Right to Marry Characterize Marriage as a Fundamental Civil and Human Right and Note the Institution's Significance to Self-Fulfillment and Personal Identity.}

The next area in which the right to choose one's spouse emerged as a sacrosanct and foundational principle was in courts' support for access to marriage for same-sex couples. The first U.S. Supreme Court case to consider marriage in the context of homosexual relationships was not actually a case about marriage; instead, Lawrence v. Texas analyzed the constitutionality of an anti-sodomy statute. ${ }^{140}$ Although the Court did not rule on the validity of same-sex marriage in Lawrence, it did once again list marriage among other protected aspects of life, based on both liberty and privacy interests. Citing Casey, and in syntax strikingly similar to the "laundry list" utilized in the Meyer decision eighty years earlier, the Court stated that the "Due Process Clause protects personal decisions relating to marriage, procreation, contraception, family relationships, child rearing, and education," regardless of one's sexual orientation. ${ }^{141}$

Lawrence was considered a landmark ruling by the lesbian, gay, bisexual, transgender, and questioning (LGBTQ) community, with one prominent legal scholar declaring, "Lawrence may well be remembered as the Brown $v$. Board of gay and lesbian America." 142 The sweeping language about fundamental rights-including, notably, the right to marry - was widely recognized as laying the groundwork for later rulings on the issue of same-sex

139 Fatin v. INS, 12 F.3d 1233, 1242 (3rd Cir. 1993).

140539 U.S. 558 (2003).

141 Id. at 559 (emphasis added).

142 Laurence H. Tribe, Lawrence v. Texas: The "Fundamental Right" that Dare Not Speak Its Name, 117 HaRv. L. Rev. 1893, 1985 (2004). 
marriage. ${ }^{143}$ In fact, only a few months after the Lawrence decision, the Massachusetts Supreme Court issued its ruling in Goodridge v. Department of Public Health, quoting Lawrence in the second paragraph of its decision granting same-sex couples the right to marry. ${ }^{144}$

Massachusetts was the first state in which the judiciary legalized gay marriage, and in the extensive Goodridge decision, the Court repeatedly emphasized the profoundly important nature of the marital relationship. Referring to marriage as "one of our community's most rewarding and cherished institutions" 145 and a "social institution of the highest importance," 146 the court focused on both the individual and community aspects of marriage, stating that "civil marriage is at once a deeply personal commitment to another human being and a highly public celebration of the ideals of mutuality, companionship, intimacy, fidelity, and family."147

Notably, the Goodridge court devoted significant attention to the concept of choice, reiterating in numerous ways throughout its opinion that "the right to marry means little if it does not include the right to marry the person of one's choice."148 This consideration was only infrequently present in earlier U.S. Supreme Court decisions regarding marriage, and its inclusion in Goodridge highlights the evolution of judicial thinking, as well as adherence to international human rights norms regarding the essential nature of choice in the marital relationship.

After Goodridge, several other state courts followed suit in holding that the denial of

143 Linda Greenhouse, Supreme Court Paved Way for Marriage Ruling With Sodomy Law Decision, N.Y. Times, Nov. 19, 2003, at A24. In fact, in his dissent in Lawrence, Justice Scalia expressed concern about the future constitutionality of laws against same-sex marriage, stating that the majority opinion in Lawrence "dismantles the structure of constitutional law that has permitted a distinction to be made between heterosexual and homosexual union, insofar as formal recognition in marriage is concerned." Lawrence, 539 U.S. at 590 (Scalia, J., dissenting).

144 Goodridge v. Dep't. of Pub. Health, 798 N.E.2d 941, 948 (Mass. 2003).

145 Id. at 949.

146 Id. at 954 (citing French v. McAnarney, 290 Mass. 544, 546 (1935)).

147 Id.

148 Id. at 958 . See also id. at 970 (Greaney, J., concurring) (stating that the right to marry "is essentially vitiated if one is denied the right to marry a person of one's choice."). 
marriage to same-sex couples violated state constitutions, including California, ${ }^{149}$ Connecticut, ${ }^{150}$ Iowa, ${ }^{151}$ New Jersey, ${ }^{152}$ and New Mexico ${ }^{153} .{ }^{154}$ These cases all proceeded from a baseline understanding that marriage is a fundamental civil and human right. Justices such as those on the Supreme Court of California spoke about the profound impact marriage can have on an individual, asserting that marriage is "the most socially productive and individually fulfilling relationship that one can enjoy in the course of a lifetime" and that " $[t]$ he ability of an individual to join in a committed, long-term, officially recognized family relationship with the person of his or her choice is often of crucial significance to the individual's happiness and well-being." 155 Unlike federal and immigration courts hearing asylum cases, these state judicial bodies easily recognized that marriage is one of the "essentials of life," 156 an institution that has a profound impact on innumerable

149 In re Marriage Cases, 183 3.Pd 384 (2008).

150 Kerrigan v. Comm'r of Pub. Health, 957 A.2d 407 (Conn. 2008).

151 Varnum v. Brien, 763 N.W.2d 862 (Iowa 2009).

152 Lewis v. Harris, 908 A.2d 196 (N.J. 2006).

153 Griego v. Oliver, 316 P.3d 865 (N.M. 2013).

154 Although Massachusetts and the five states listed above are the only states in which the highest state courts affirmed the right to same-sex marriage, several other state courts have ruled on the subject. Some courts, such as the Hawaii Supreme Court and the Alaska Superior Court, issued decisions that were rendered moot by legislative action. Baehr v. Lewin, 852 P.2d 44 (Haw. 1993), superseded by Constitutional Amendment 2 of 1998, enacted as HAW. Const. art. I, § 23; Brause v. Bureau of Vital Statistics, 3AN-95-6562 CI, 1998 WL 88743 (Alaska Super. Ct. Feb. 27, 1998), superseded by Ballot Measure 2 of 1998, enacted as ALASKA ConsT. art. $1, \S 25$. In other states, the issue before the court was not the institution of marriage itself but the benefits of marriage that were unavailable to same-sex couples. For example, in Baker v. State, 170 Vt. 194 (1999), the Vermont high court focused on both marriage and alternatives such as civil unions (although the Vermont legislature later passed a bill, and in 2009 overrode the governor's veto, to permit same-sex marriage (Act to Protect Religious Freedom and Promote Equality in Civil Marriage, No. 3, § 5, 2009 Vt. Acts \& Resolves 1, 2, amending $15 \mathrm{VT}$. STAT. ANN. tit. 15, $\S 8(2013)$ to read, "Marriage is the legally recognized union of two people.")). Finally, challenges to constitutional amendments prohibiting same-sex marriage in several states, including Utah (Kitchen v. Herbert, 961 F.Supp.2d 1181 (D. Utah 2013), affirmed by Kitchen v. Herbert, No. 13-4178, 2014 WL 2868044 (10th Cir. June 25, 2014)), Oklahoma (Bishop v. U.S. ex rel. Holder, 962 F.Supp.2d 1252 (N.D. Okla. 2014)), and Michigan (DeBoer v. Snyder, No. 12-CV-10285, 2014 WL 1100794 (E.D. Mich. Mar. 21, 2014)), have been heard by U.S. District Courts in those jurisdictions. The Tenth Circuit was the first federal appeals court to strike down a state ban on same-sex marriage post-Windsor, but the decision has been stayed pending any appeal to the Supreme Court. Kitchen, 2014 WL 2868044, at *32.

155 In re Marriage Cases, 43 Cal.4th 757, 816 (2008).

156 In re T-Z-, 24 I. \& N. Dec. 163, 171 (B.I.A. 2007). 
aspects of a person's existence.

The idea that the marital relationship is an expression of one's identity and is at the root of personal fulfillment became a more prominent feature in decisions concerning marriage as the debate surrounding same-sex unions evolved. ${ }^{157}$ As the Supreme Court of California stated in In Re Marriage Cases, "the opportunity to publicly and officially express one's love for and long-term commitment to another person by establishing a family together with that person also is an important element of self-expression that can give special meaning to one's life." 158

The notions of marriage as fundamental to one's public and private identity and the ability to enter into the bond with a person of one's choice as essential to human freedom is evidenced by the words of the countless individuals who swear marriage vows each day. In describing how she felt the day after she married her partner of forty years, Edie Windsor stated,

The fact is, marriage is this magic thing ... I mean forget all the financial stuff-marriage ... symbolizes commitment and love like nothing else in the world. And it's known all over the world. I mean, wherever you go, if you're married, that means something to people, and it meant a difference in feeling the next day. ${ }^{159}$

Other same-sex couples who were permitted to exchange marriage vows after years of cohabitation have echoed Ms. Windsor's views upon being legally married. "Going through the ceremony, it really hit me. When he said, 'Therefore, by the powers vested in me by the State of California,' I blubbered. We weren't any different than we had been for the previous 55 years, but yet, we were." 160 Another recently married woman stated, "Truth is, it changed our lives completely." 161 The intensity of feeling was surprising to one newlywed, who declared, "[T]hings have felt different between us in the past four or five

157 See, e.g., Goodridge v. Dep't. of Pub. Health, 798 N.E.2d 941, 948 (Mass. 2003) (stating that Lawrence "reaffirmed the central role that decisions whether to marry or have children bear in shaping one's identity.").

15843 Cal.4th at 817.

159 Totenberg, supra note 5.

160 Ron and Tom's Story, WhY MARRIAGE MatTERS, http://www.whymarriagematters.org/video/entry/ronand-toms-story [http://perma.cc/3PZT-TY6X].

161 Cristina and Monica, Why MARRIAGE MATTERS, http://www.whymarriagematters.org/video/entry/ cristina-and-monica [http://perma.cc/WT4N-VNY4]. 
months since we've been married. Things have felt deeper and more loving in a way that I didn't anticipate at all."'162

Although the emotions are unquestionably profound-in fact, research by scientists at Michigan State University has shown that married people are happier than those who are single ${ }^{163}$-marriage is, of course, about more than just feelings. Studies have concluded that married couples live longer ${ }^{164}$ and that married men make more money. ${ }^{165}$ As courts have recognized, marriage is also instrumental in the expression of one's identity. Novelist Elizabeth Gilbert explains it well:

In the modern industrialized Western world . . . the person whom you choose to marry is perhaps the single most vivid representation of your own personality. Your spouse becomes the most gleaming possible mirror through which your emotional individualism is reflected back to the world. There is no choice more intensely personal, after all, than whom you choose to marry; that choice tells us, to a large extent, who you are. ${ }^{166}$

Lastly, in addition to its deeply personal and emotionally significant aspects, marriage is also a state-regulated institution, one that implicates both legal rights and responsibilities. As the Supreme Court of Vermont stated in Baker v. State of Vermont, "while many have noted the symbolic or spiritual significant of the marital relation, it is plaintiffs' claim

162 Tobi and Janee, Why MARRIAGE MATTERS, http://www.whymarriagematters.org/video/entry/tobi-andjanee [http://perma.cc/REE4-Q6H7].

163 Andy Henion \& Stevie Yap, Marriage May Make People Happier, MSU TodaY (May 30, 2012), http:// research.msu.edu/stories/marriage-may-make-people-happier [http://perma.cc/L72P-B9UY].

164 See Marriage linked to better survival in middle age: Study highlights importance of social ties during midlife, ScI. Dally (Jan. 10, 2013), http://www.sciencedaily.com/releases/2013/01/130110102342.htm [http:// perma.cc/SU9Z-TDNZ]. See also Marriage, Focus ON THE FAMILY, http://www.focusonthefamily.com/ socialissues/social-issues/marriage.aspx [http://perma.cc/W8BV-CUXD] ("In general, married people live longer, spend less time in the hospital, have higher incomes and enjoy greater emotional support."); Why Marriage Should be Privileged in Public Policy, FamiLy ReSEARCH COUNCIL, http://www.frc.org/insight/whymarriage-should-be-privileged-in-public-policy [http://perma.cc/ND89-2QTW] ("Marriage also positively affects adults, as married people are more likely to be healthy, productive, and engaged citizens. They have better emotional and physical health and live longer than do unmarried people.").

165 Abbigail J. Chiodo \& Michael T. Owyang, For Love or Money: Why Married Men Make More, ReGional ECONOMIST (April 2002), http://www.stlouisfed.org/publications/re/articles/?id=443 [http://perma. cc/UPU8-FTHP].

166 Elizabeth Gilbert, Committed: A Skeptic Makes Peace With Marriage 35 (2010). 
to the secular benefits and protections of a singularly human relationship that, in our view, characterizes this case." ${ }^{167}$ Access to these benefits is therefore another critically important aspect of the marital relationship that courts take into account when considering or attempting to valuate marriage.

In United States v. Windsor, the U.S. Supreme Court noted that DOMA affects more than " 1,000 federal statutes and the whole realm of federal regulations." 168 Similarly, in Goodridge, the Massachusetts Supreme Court stated that "the benefits accessible only by way of a marriage license are enormous, touching nearly every aspect of life and death," and delineated several of the "hundreds of statutes" implicating marital benefits such as inheritance; medical insurance, access and decision-making; veterans' benefits; and evidentiary rights. ${ }^{169}$ In Varnum, the Supreme Court of Iowa also considered the "disadvantages and fears [same-sex couples] face each day due to the inability to obtain a civil marriage in Iowa," including issues ranging from the serious-healthcare and health insurance, pension and tax benefits, and adoption rights - to the relatively trivial, such as health club memberships. ${ }^{170}$ Access (or the lack thereof) to this panoply of benefits was an indicator for courts that the marital relationship was not only meaningful on an emotional level but a practical necessity when navigating modern life.

\section{In Striking Down the Defense of Marriage Act, the Supreme Court Affirmed the Inherent Dignity of the Marital Relationship.}

In June 2013, the Supreme Court issued a major ruling concerning the right to marriage. The Court had two related cases before it. The first was Hollingsworth v. Perry, ${ }^{171}$ which challenged the legality of Proposition 8 , a California ballot initiative that amended the state constitution to define marriage as a union between a man and a woman (following the California Supreme Court's holding in In Re Marriage Cases that limiting marriage to opposite-sex couples violated the state constitution). The second was United States $v$.

167744 A.2d 864, 888-89 (Vt. 1999). See also Goodridge v. Dep't. of Pub. Health, 798 N.E.2d 941, 948 (Mass. 2003) ("Marriage is a vital social institution. The exclusive commitment of two individuals to each other nurtures love and mutual support; it brings stability to our society. For those who choose to marry, and for their children, marriage provides an abundance of legal, financial, and social benefits.").

168 133 S.Ct. $2675,2690(2013)$.

169 Goodridge, 798 N.E.2d at 955.

170 Varnum v. Brien, 763 N.W.2d 862, 873 (Iowa 2009).

171133 S.Ct. at 2652. 
Windsor, ${ }^{172}$ a case that sought to invalidate $\S 3$ of the federal Defense of Marriage Act, ${ }^{173}$ which excluded same-sex spouses from the definition of marriage, and therefore, as detailed above, denied them access to a vast number of federal benefits.

In a historic ruling in Windsor, the Court held $\S 3$ of the Defense of Marriage Act unconstitutional, finding that it violated the liberty protections inherent in the Fifth Amendment. The Court stated that "DOMA singles out a class of persons deemed by a State entitled to recognition and protection to enhance their own liberty. It imposes a disability on the class by refusing to acknowledge a status the State finds to be dignified and proper." 174 The institution of marriage "is more than a routine classification for purposes of certain statutory benefits," opined Justice Kennedy, and "the State's decision to give this class of persons the right to marry conferred upon them a dignity and status of immense import ... [and the State's] role and its power in making the decision enhanced the recognition, dignity, and protection of the class in their own community." 175 Much of the Court's decision in Windsor focused on these concepts-the dignity conferred by the marital relationship and the relationship between marriage and concepts of "personhood"-once again reinforcing the now well-established view that marriage is central to one's happiness, fulfillment and identity.

The Court did not address the merits in Hollingsworth due to its finding that the petitioners did not have standing to appeal the lower court's judgment. ${ }^{176}$ Nevertheless, the opening sentence in the Respondent's brief in the case demonstrates that the meaning and significance of marriage also played a pivotal role in considerations of the case:

This case is about marriage, "the most important relation in life," a relationship and intimate decision that this Court has variously described at least 14 times as a right protected by the Due Process Clause that is central for all individuals' liberty, privacy, spirituality, personal autonomy, sexuality and dignity; a matter fundamental to one's place in society; and an expression of love, emotional support, public commitment and social

172 Id. at 2675.

173 See supra note 3.

174 Windsor, 133 S.Ct. at 2695-96.

175 Id. at 2692.

176 Id. at 2659. 
status. ${ }^{177}$

And the lack of a substantive decision in Hollingsworth certainly does not signal an end to the debate. In fact, in his scathing dissent in Windsor, Justice Scalia predicted that the language in the majority opinion in that case will inevitably be used to invalidate state laws denying same-sex couples the right to marry and that this "second, state-law shoe to be dropped later" may occur as early as "next Term." 178

Justice Scalia's projection may not be too farfetched, particularly since public opinion in the United States regarding the right to marriage continues to evolve at a rapid pace. Support for same-sex marriage has been rising steadily since 2004, a year after the Massachusetts Supreme Court issued its decision in Goodridge. ${ }^{179}$ A Fox News poll taken three months prior to the rulings in Windsor and Hollingsworth found that fifty-three percent of registered voters believed that same-sex couples have a constitutional right to marry. ${ }^{180}$ This growing acceptance of marriage as a fundamental constitutional, civil, and human right acknowledges the significance of both the institution itself and the element of choice that defines it.

This evolution of societal views on the issue appears to have been considered by the Supreme Court in a number of cases in this context. In Lawrence, Justice Kennedy undertook pages of historical analysis of the criminalization of sodomy and changing concepts of morality, and in defense of his invalidation of the anti-sodomy statute, he remarked that

177 Brief for Respondents at 1, Hollingsworth v. Perry, 133 S.Ct. 2652 (2013) (internal citation omitted) (emphasis in original).

178 Windsor, 133 S.Ct. at 2705 (Scalia, J., dissenting). Justice Scalia's assessment is likely correct, for as indicated in footnote 154 supra, at the time of publication, a ruling by the Tenth Circuit Court of Appeals invalidating Utah's ban on same-sex marriage has been stayed pending any appeal to the Supreme Court. Kitchen v. Herbert, No. 13-4178, 2014 WL 2868044, at *32 (10th Cir. June 25, 2014). Challenges to similar bans in other states also appear to be headed for the high court, see, e.g., Steve Helber, Race on Same-Sex Marriage Cases Runs Through Virginia, WASH. Post (Feb. 3, 2014), http://www.washingtonpost.com/ politics/race-on-same-sex-marriage-cases-runs-through-virginia/2014/02/03/934d9306-8c50-1 le3-95dd36ff657a4dae_story.html [http://perma.cc/587-GKBM].

179 Nate Silver, How Opinion on Same-Sex Mariage Is Changing, and What It Means, N.Y. Times (Mar. 26, 2013), http://fivethirtyeight.blogs.nytimes.com/2013/03/26/how-opinion-on-same-sex-marriage-is-changingand-what-it-means/ [http://perma.cc/4XAY-XYGN]. Silver notes that support for same-sex marriage rose at a rate of two percentage points a year, to $37 \%$ in 2006 and $41 \%$ in 2008 , with support beginning to outweigh opposition in 2010-2011.

180 Same-Sex Marriage, Gay Rights, PollingRePORT.com, http://www.pollingreport.com/civil.htm [http:// perma.ce/W7VC-BE4S]. 
only a minority of states enforced laws against sodomy at that time. ${ }^{181}$ Similarly, in Windsor, the Court noted that twelve states and the District of Columbia "decided that same-sex couples should have the right to marry and so live with pride in themselves and their union and in a status of equality with all other married persons." 182

The Court's attention to public opinion regarding marriage allowed it to rest its holdings on solid sociological footing. At this point in history, the debate over and fight for marriage equality is far from concluded. However, what is certain is that both sides of the divide believe that marriage is a sacred union. ${ }^{183}$ Whether that view is the basis of arguments for restricting or expanding the right to access the institution, law and society's recognition of marriage as fundamental to civil and human rights is indisputable.

\section{International Law Requires Free Choice and Consent in Order to Recognize a Marriage as Valid}

International treaties have directly addressed the issue of forced marriage in a number of contexts, creating a vast body of international law opposing forced marriage and requiring consent before recognizing a marriage as valid. The Universal Declaration of Human Rights, a foundational document that was considered at the inaugural session of the United Nations General Assembly in 1946 and adopted unanimously in 1948, states in Article 16 that "(1) [m]en and women ... have the right to marry and found a family" and that "(2)

181 Lawrence v. Texas, 539 U.S. 558, 573 (2003) ("The 25 States with laws prohibiting the relevant conduct referenced in the Bowers decision are reduced now to 13, of which 4 enforce their laws only against homosexual conduct.").

182 Windsor, $133 \mathrm{~S} . \mathrm{Ct}$. at 2689 . In addition to the states that allow same-sex marriage, some states have extended legal rights to same-sex couples through mechanisms short of marriage such as civil unions or domestic partnerships.

183 Dr. James Dobson, Marriage Under Fire: Why We Must Win This Battle 8 (2004) ("Given this unbroken continuity, one might begin to suspect that something mystical within human nature must be drawing the sexes together-not just for purposes of reproduction as with animals-but to satisfy an inexpressible longing for companionship, intimacy and spiritual bonding."); Donna Brazile, What the Sanctity of Marriage Means, CNN (June 28, 2013), http://www.cnn.com/2013/06/28/opinion/brazile-same-sex-marriage/ [http:// perma.cc/5PP9-VTEG] ("marriage is an important enough institution that it should apply to humans equally, regardless of gender"); Ryan T. Anderson, Marriage: What It Is, Why It Matters, and the Consequences of Redefining $I t$, THE Heritage Foundation Backgrounder No. 2775 (Mar. 11, 2013), http://www.heritage.org/ research/reports/2013/03/marriage-what-it-is-why-it-matters-and-the-consequences-of-redefining-it [http:// perma.cc/AC68-ET7J] ("Marriage is a uniquely comprehensive union. It involves a union of hearts and minds, but also - and distinctively - a bodily union made possible by sexual complementarity. . . "Marriage as the union of man and woman is true across cultures, religions, and time. The government recognizes but does not create marriage. Marriage is the fundamental building block of all human civilization."). 
[m]arriage shall be entered into only with the free and full consent of the intending spouses." 184 According to experts, the UDHR not only affirms the human right to marriage, but also makes clear that the presence of consent is an essential and indispensable condition, or "a sine qua non for the validity of the marriage." 185 In fact, scholars have argued that "[ $t]$ he prohibition of marriage without free and full consent of the intending spouses rules out all forced marriage" under international law. ${ }^{186}$

Subsequent treaties adopted the language on marriage utilized by the UDHR and addressed the issue of consent and forced marriage in a variety of different contexts. The U.N. Supplementary Convention on the Abolition of Slavery, the Slave Trade, and Institutions and Practices Similar to Slavery, a treaty to which the United States acceded in 1967, includes forced marriage in the section that defines "institutions and practices similar to slavery." 187 Article 1(c)(i) of the Convention describes as enslaved "a woman, [who,] without the right to refuse, is promised or given in marriage on payment of a consideration in money or in kind to her parents, guardian, family or any other person or group." 188 Underscoring the necessity of eradicating forced marriage, Article 2 codifies the obligation of State Parties to "encourage the use of facilities whereby the consent of both parties to a marriage may be freely expressed in the presence of a competent civil or religious

184 Universal Declaration of Human Rights, G.A. Res. 217A. at 74, U.N. GAOR, 3d Sess., Ist plen. mtg. U.N. Doc. A/810 (Dec. 12, 1948). Similar language is replicated in regional instruments, e.g., Convention for the Protection of Human Rights and Fundamental Freedoms, art. 12, opened for signature Nov. 4, 1950, Europ. T.S. No. 5, 213 U.N.T.S. 221 (entered into force Sept. 3, 1953) ("Men and women of marriageable age have the right to marry and to found a family"); the Protocol to the African Charter on Human and Peoples' Rights on the Rights of Women in Africa (Maputo Protocol), art. 6, Sept. 13, 2000, CAB/LEG/66.6 (entered into force Nov. 25, 2005) ("States Parties shall ensure that women and men enjoy equal rights and are regarded as equal partners in marriage. They shall enact appropriate national legislative measures to guarantee that: no marriage shall take place without the free and full consent of both parties."); and the American Convention on Human Rights, art 17.3, July 18, 1978, O.A.S.T.S. 36, 1144 U.N.T.S. 123 ("No marriage shall be entered into without the full and free consent of the intending spouses.").

185 Gudmundur Alfredsson \& Asbjorn Eide, The Universal Declaration of Human Rights: A COMmon Standard of ACHIEvement 333 (1999).

186 Manfred Nowak, U.N. Covenant on Civil and Political Rights, CCPR Commentary 414-15 (1993).

187 Supplementary Convention on the Abolition of Slavery, the Slave Trade, and Institutions and Practices Similar to Slavery, art. 1(c)(i), opened for signature Sept. 7, 1956, art. 1, 18 U.S.T. 3201, 226 U.N.T.S. 3. The United States' accession to this treaty in 1967 has the same legal effect as ratification.

188 Id. 
authority . . .."189

The UDHR's focus on "free and full consent" as a requisite to marriage was also echoed in later treaties. The Convention on Consent to Marriage, Minimum Age for Marriage and Registration of Marriages "recalls" Article 16 of the UDHR and "reaffirms" that all states should ensure "complete freedom in the choice of a spouse" by stating in Article 1 that "no marriage shall be legally entered into without the full and free consent of both parties." 190 This language was reproduced almost identically in two other treaties modeled on the UDHR - the International Convention on Civil and Political Rights (ICCPR) ${ }^{191}$ and the International Convention on Economic, Social and Cultural Rights (ICESCR). ${ }^{192}$ All three instruments base their proclamations regarding the essential nature of consent on the notion that marriage is a singularly significant institution and the basis of the family unit, which in turn is "the natural and fundamental group unit of society." 193

The most recent restatement of the importance of consent to marriage can be found in the United Nations Convention on the Elimination of All Forms of Discrimination Against Women (CEDAW). Article 16(1) of that treaty asserts that "States Parties shall . . ensure, on a basis of equality of men and women: (a) the same right to enter into marriage; [and] (b) the same right freely to choose a spouse and to enter into marriage only with their free and full consent." 194 By the time the treaty came into force in 1981, the message enshrined in Section (b) was so widely accepted that the Section was adopted by consensus with no

189 Id.

190 Convention on Consent to Marriage, Minimum Age for Marriage, and Registration of Marriages, art. 16, Dec. 10, 1962, 521 U.N.T.S. 231. The United States signed the Convention in 1962 but has not yet ratified it.

191 International Covenant on Civil and Political Rights, art. 23(3) adopted Dec. 16, 1966, S. Exec. Doc. E, 95-2, at 30, 999 U.N.T.S. 171, 179 (entered into force Mar. 23, 1976),("No marriage shall be entered into without the free and full consent of the intending spouses."). The United States ratified the ICCPR on April 2, 1992.

192 International Convention on Economic, Social and Cultural Rights, art. 10(1), opened for signature Dec. 16, 1966, 933 U.N.T.S. 3, 7 (entered into force Jan. 3, 1976) ("Marriage must be entered into with the free consent of the intending spouses."). The United States signed the ICESCR in 1977 but has not ratified the treaty.

$193 I d$. This language is identical to that used in the UDHR and ICCPR.

194 United Nations Convention on the Elimination of All Forms of Discrimination Against Women, art. 16(1), opened for signature Mar. 7, 1966, 1249 U.N.T.S. 13, 20 (entered into force Sept. 3, 1981). The United States signed CEDAW in July 1980 but has not yet ratified the treaty. 
suggested changes or amendments noted. ${ }^{195}$

What is notable in the aforementioned international instruments is not only their unequivocal pronouncements that free and full consent is essential for lawfully recognized entry into a marital union, but that nothing more than the lack of this consent is required to invalidate a marriage. The treaties do not speak of physical or sexual violence or any other exacerbating factors as being necessary to nullify a marriage in the eyes of international law. Rather, the lack of choice, or the forced marriage itself, is a per se harm.

The U.S. Constitution makes treaties the "supreme law of the land," 196 and courts have long held that both international and customary international law are relevant to the adjudication of domestic cases. ${ }^{197}$ The application of international law in the asylum context is arguably even more appropriate, because as the Supreme Court stated in I.N.S. v. Cardoza-Fonseca, "[i]f one thing is clear from the legislative history of the new definition of 'refugee,' and indeed the entire 1980 Act, it is that one of Congress' primary purposes was to bring United States refugee law into conformance with the 1967 United Nations Protocol Relating to the Status of Refugees." 198

Accordingly, U.S. immigration authorities recognize the importance of international law and treaties such as those discussed above as guides to human rights norms across the world, specifically stating that "[t]he evaluation of gender-based [asylum] claims must be viewed within the framework provided by existing international human rights

195 U.N. GAOR, Comm'n on the Status of Women, 26th Sess., Summary Records of the 650th meeting, I 70, U.N. Doc. E/CN.6/SR.650 (Sept. 27, 1976).

196 U.S. Const. art. VI, § 2. ("[A]11 Treaties made, or which shall be made, under the Authority of the United States, shall be the supreme Law of the Land; and the Judges in every State shall be bound thereby, any Thing in the Constitution or Laws of any State to the Contrary notwithstanding.").

197 See The Paquete Habana, 175 U.S. 677, 700 (1900) ("International law is part of our law, and must be ascertained and administered by the courts of justice of appropriate jurisdiction as often as questions of right depending upon it are duly presented for their determination."). Therefore, although a treaty may not have been ratified by the United States, it may still be accorded significant weight as an indicator of customary international law.

198480 U.S. 421,436 (1987). In considering the intersection between asylum law and international norms, the Court in Cardoza-Fonseca recognized the relevance of not only international law and treaties to asylum jurisprudence, but also of other international interpretations such as those contained in the United Nations High Commissioner for Refugees' (UNHCR) Handbook on Procedures and Criteria for Determining Refugee Status, which the Court stated can provide "significant guidance" to analysis of U.S. asylum law. Id. at 440 n.22. 
instruments." 199 However, despite the international community's near unanimous and explicit support of the necessity of choice and consent in marriage and its resulting condemnation of forced marriage, U.S. immigration and federal courts' interpretations of asylum law have routinely deviated from this international consensus by declining to recognize forced marriage as a persecutory act.

\section{The Disconnect Between Forced Marriage Asylum Law and Domestic Interpretations of the Right to Marry}

As demonstrated in Parts II and III above, the right to marry the person of one's choosing is well-established in both U.S. constitutional law and international law. Marriage has been held to be a sacred institution, and freedom of choice in marriage has been repeatedly and unequivocally acknowledged as central to human dignity by U.S. courts and international bodies. Unlike federal and immigration courts, administrative agency interpretations and treaties have established the basic tenet that forced marriage is persecutory because it breaches the fundamental right to full and free consent in marriage. From all these sources, it is clear that even without considering the harms that typically accompany a forced marriage (such as domestic violence, marital rape, FGM, loss of liberty, etc.), because marriage is such an important part of life, the act of entering into the presumably lifelong relationship against one's will is itself a significant violation. And the persecution becomes more profound when one considers that a forced marriage necessarily prevents its victim from exercising her fundamental right to marry a person she does love. The collateral consequence of forced marriage is to prevent its victim from entering into a willing marriage, which, as discussed previously, is a social institution that is widely understood as being vital to one's identity, dignity, autonomy, and well-being.

Turning to U.S. courts' interpretation of immigration law, the legal picture appears drastically different. Courts analyzing asylum claims are dismissive of the notion of forced marriage as persecution, despite support for the proposition in domestic, international, and even general immigration law. They routinely characterize forced marriage as mere harassment or as culturally accepted arranged marriage, ignoring the fact that the U.S. Supreme Court created a constitutionally protected right to marry the person of one's choosing, out of reverence for the institution and recognition of the impact that the decision of who to marry has on a person's life. The right to marry is, as the Court stated in Loving, a "vital

199 Memorandum from Phyllis Coven, Office of INT'L AfFalRs, to INS Asylum Officers, HQASM Coordinators, OFFICE OF INT'L AFFAIRs (May 26, 1995) (setting guidelines regarding adjudicating asylum cases on the basis of gender), available at $\mathrm{http}: / \mathrm{www} . \mathrm{state}$.gov/s/1/65633.htm [http://perma.cc/3L9X-KQCE]. 
personal right essential to the orderly pursuit of happiness." ${ }^{200}$ Marriage has also been held to be "one of our community's most rewarding and cherished institutions"201 and a "social institution of the highest importance." ${ }^{202}$ Federal and state courts have also opined on the dignity, identity, and status inherent in the marital relationship. Yet, asylum jurisprudence has failed to recognize the harm of forcing women to enter into marriage.

Courts' dismissive labeling of applicants' objections to forced marriage as "personal preferences" flies in the face of a body of asylum jurisprudence that aims to protect individuals who are expressing deeply held, personal opinions from persecution. As the Supreme Court and others have noted, the choice of a spouse is one of the most significant and meaningful decisions one makes in a lifetime. That this decision is not seen as deserving serious judicial consideration, much less protection, stands as a substantial gap in asylum law's protection.

Persecution, as detailed in Section I.B.1, is a broad concept that includes not just physical violence but also acts that are harmful to an "individual's deepest beliefs" ${ }^{203}$ or deprive one of an "essential of life"204. Under that definition, forcing someone to enter into the uniquely profound and impactful relationship of marriage against her will-and thereby preventing her from exercising her "fundamental freedom" to marry a person of her choice ${ }^{205}$ - must be a persecutory act. Immigration and federal courts' failure to conform to both their own definitions of persecution as well as the prevailing jurisprudence on marriage is plainly incorrect. Courts should therefore take steps to rectify this wrong not only by recognizing forced marriage as a harm rising to the level of persecution-and thereby meriting asylum protection-but also by establishing forced marriage as a per se form of persecution, a violation in and of itself that does not require proof of any additional, related, or "component" harms.

Due to the failure to recognize forced marriage as a per se harm; courts' denials of legally viable forced marriage claims; the lack of clarity surrounding $\mathrm{Gao}$; and the un-

200 Loving v. Virginia, 388 U.S. 1, 12 (1967).

201 Goodridge, v. Dep’t. of Pub. Health, 798 N.E.2d 941, 949 (Mass. 2003).

202 Id. at 954 (citing French v. McAnarney, 290 Mass. 544, 546 (1935)).

203 Fatin v. INS, 12 F.3d 1233, 1242 (3d Cir. 1993).

204 In re T-Z-, 24 I. \& N. Dec. 163, 171 (B.I.A. 2007).

205 Loving, 388 U.S. at 12. See also Goodridge, 798 N.E.2d at 958 ("[T] [Te right to marry means little if it does not include the right to marry the person of one's choice"). 
certainty surrounding the availability of asylum protection in the courts for individuals fleeing forced marriage, practitioners litigating forced marriage cases must often rely on alternative bases for relief in order to avoid directly confronting the issue of whether forced marriage, standing alone, constitutes per se persecution.

As stated in the Introduction, one common strategy for avoiding the question of whether forced marriage is itself persecution is to tell the "Abusive Elderly Polygamist" story and focus on "component parts," or the other forms of persecution that often exist within a forced marriage. This allows an adjudicator to find persecution on a more commonly accepted ground such as rape, ${ }^{206}$ domestic violence, ${ }^{207}$ kidnapping or deprivation of liberty, ${ }^{208}$ lack of reproductive control, ${ }^{209}$ forced labor, ${ }^{210}$ severe economic deprivation, ${ }^{211} \mathrm{FGM},{ }^{212}$ or emotional or psychological abuse ${ }^{213}$. Alternatively, attorneys can also make claims based on the consequences faced by women who refuse and/or flee from forced marriages. This type of persecution, which is established in the "Violent Honor Crimes Story," takes a

206 See Hernandez-Montiel v. INS, 225 F.3d 1084, $1097-98$ (9th Cir. 2000); Lopez-Galarza v. I.N.S., 99 F.3d 954, 958 (9th Cir. 1996); Matter of D-V-, 21 I. \& N. Dec. 77 (B.I.A. 1993).

207 See In re R-A-, 22 I. \& N. Dec. 906 (BIA 1999), vacated, 22 I. \& N. Dec. 906 (Op. Att'y Gen. 2001), and remanded, 23 I. \& N. Dec. 694 (Op. Att'y Gen. 2005), stay lifted, 24 I. \& N. Dec. 629 (Op. Att'y Gen. 2008), asylum granted in an unpublished Immigration Judge opinion on December 10, 2009; Brief of Dep't. of Homeland Security, Matter of L-R- (B.I.A. April 13, 2009), available at http://cgrs.uchastings.edu/sites/ default/files/Matter_of_LR_DHS_Brief_4_13_2009.pdf [http://perma.cc/DN4J-6GDC], asylum granted in an unpublished Immigration Judge opinion on Aug. 4, 2010.

208 See Gomez-Zuluaga v. U.S. Att'y. Gen., 527 F.3d 330, 341 (9th Cir. 2008); Delgado v. Mukasey, 508 F.3d 702, 707 (2d Cir. 2007); Phommasoukha v. Gonzales, 408 F.3d 1011, 1016 (8th Cir. 2005).

209 See Fei Mei Cheng v. U.S. Att'y. Gen., 623 F.3d 175, 184 (3rd Cir. 2010); Matter of Y-T-L-, 23 I. \& N. Dec. 601,603 (B.I.A. 2003).

210 See Lhanzom v. Gonzales, 430 F.3d 833, 847 (7th Cir. 2005); Phommasoukha v. Gonzales, 408 F.3d 1011,1015 (8th Cir. 2005); Jhup v. Ashcroft, 376 F.3d 898 (9th Cir. 2004) (implying that forced labor may be persecution, but finding that one day of forced labor was insufficient to rise to the level of persecution).

211 See Matter of Acosta, 19 I. \& N. Dec. 211, 222 (B.I.A. 1985), overruled on other grounds by Matter of Mogharrabi, 19 I. \& N. Dec. 439 (B.I.A. 1987) (economic deprivation can be persecution if the deprivation is "so severe that [it] constitute[s] a threat to an individual's life or freedom."). See also Vicente-Elias v. Mukasey, 532 F.3d 1086, 1089 (10th Cir. 2008) (economic hardships may qualify for persecution in two ways: first, when the government imposes penalties so severe that it jeopardizes the petitioners life or freedom; second, when the government deliberately places the petitioner at a severe economic disadvantage even though he or she is spared the bare essentials of life); In re T-Z-, 24 I. \& N. Dec. 163 (B.I.A 2007).

212 See In re Kasinga, 21 I. \& N. 357 (B.I.A. 1996).

213 See Mashiri v. Ashcroft, 383 F.3d 1112 (9th Cir. 2004) 
more traditional form, including threats of death or other bodily harm, beatings, and confinement. ${ }^{214}$

Even when membership in a particular social group that makes one vulnerable to forced marriage is the root cause of an individual seeking refuge in the United States, when considering nexus, attorneys often attempt to shoehorn their clients' claims into more traditional nexus grounds, such as political opinion or religion. A political claim based on forced marriage can be made by arguing that when a woman refuses a forced marriage, she is expressing either an actual or imputed "feminist" political opinion ${ }^{215}$ by speaking out against male domination, expressing her belief that women should exercise control over their own bodies or destinies, or behaving in a way that is at odds with cultural norms. A religion-based claim typically consists of an argument that a woman is being persecuted for expressing religious beliefs that differ from those of her father or male relatives, for example, that her interpretation of the Quran does not require women to submit to their families' wishes regarding the choice of a spouse. ${ }^{216}$

While it is a great solace to individual clients (and their attorneys) that protection from forced marriage can be obtained on these alternative bases, the limitations imposed by the lack of a per se rule are troubling in two fundamental respects. First, relying on the component parts of forced marriage to prove persecution requires an applicant's narrative to adhere to a certain "stock story" 117 and promotes reliance on certain factual premises that may ultimately be difficult to prove for many women who fear forced marriage.

For example, the current legal regime would almost certainly fail to provide asylum protection to a woman who objected to a forced marriage but could not provide evidence

\section{See supra note 10.}

215 A political opinion can either be openly expressed or can be imputed to an individual based on his or her actions. See Matter of S-P-, 21 I. \& N. Dec. 486, 497 (B.I.A. 1996).

216 See, e.g., Matter of S-A-, 22 I. \& N. Dec. 1328, 1336 (B.I.A. 2000) (granting asylum on religion grounds to a young woman from Morocco who refused to submit to her father's restrictions because she did not share his orthodox Muslim beliefs).

217 Stock stories are standard narratives that reflect "normal" or typical accounts of how the world works. They allow us to interpret and understand events based on limited facts and information, and with minimal analysis, by relying on assumptions about how events usually proceed and therefore how things should proceed in the current instance. See Anthony G. Amsterdam \& Jerome Bruner, Minding the Law: How Courts Rely on Storytelling, and How Their Stories Change the Ways We Understand the Law-and Oursfives 121 (2000); StePhen Ellmann et al., Lawyers and Clients: Critical Issues in InTerviewing AND Counseling 176-80 (2009); Gerald P. Lopez, Lay Lawyering, 32 UCLA L. Rev. 1, 3 (1984). 
that her intended spouse was potentially abusive. This is despite the fact that, in the domestic context, the non-consensual union itself would certainly be understood as violating her fundamental rights. Advocates therefore feel compelled to rely on the component bases described above and focus their claim on the "parade of horribles" that may occur in a forced marriage. While it is certainly reprehensible for a young girl to be married against her will to a man with a known history of violence, this does not diminish the harm inherent in a forced marriage itself, nor should it suggest that a woman who cannot demonstrate that she will face such physical abuse is not entitled to the protection the law should provide. Indeed, as articulated above, even if a potential husband is known to be a kind man, the fact remains that marriage is so crucially significant to one's identity, life, and being that the inability to choose whom to enter into the relationship with is a violation constituting persecution.

The troubling aspects of the stock "woman as victim" narrative have been well-documented and analyzed in the scholarly literature. ${ }^{218}$ The effective requirement to portray women as victims by emphasizing their vulnerabilities to rape, domestic violence, and other gender-based subjugation would be eliminated by shifting the focus of asylum claims based on forced marriage to the applicant's inability to choose. Shifting the focus would also infuse gender neutrality into the analysis because notions of choice impact men equally, and advocates would no longer feel compelled to emphasize the most pitiable aspects of their female clients' lives and experiences.

Moving beyond the individual claim, the fact that component harm claims, political opinion-based claims, and religion-based claims may currently be the only ways to obtain asylum for a victim of forced marriage significantly limits the advancement of asylum jurisprudence. By not recognizing forced marriage itself as the harm and deprivation that it unquestionably is, asylum law not only ignores prevailing legal and societal norms re-

218 See, e.g., Leigh Goodmark, When Is A Battered Woman Not A Battered Woman? When She Fights Back, 20 YALE J.L. \& FEMINISM 75 (2008) (describing a phenomenon whereby in order to receive protection from domestic violence, survivors are encouraged to adhere to the prevailing "victim" narrative and downplay any efforts to fight back or protect themselves); Adele M. Morrison, Changing the Domestic Violence (Dis) Course: Moving from White Victim to Multi-Cultural Survivor, 39 U.C. DAvIs L. Rev. 1061, 1078 (2006) (theorizing that the identity of a battered woman has been constructed only in reference to a white victim and advocating for recognition of a more inclusive multi-cultural survivor identity); Michelle VanNatta, Constructing the Battered Woman, 31 FeminisT STUD. 416 (2005) (problematizing adherence to the concept of a "normal" or "ideal" battered woman); John B. Mitchell, Narrative and Client-Centered Representation: What Is a True Believer to Do When His Two Favorite Theories Collide?, 6 CLINICAL L. Rev. 85, 91-95 (1999) (exploring the "dark side" of narrative theory, the creation of scripts that require individuals to fit into stock legal categories and conceptions, such as "the victim"). 
garding marriage, but also severely constrains the natural evolution of what it means to be persecuted under asylum law.

To cite a relevant example, although it is now well-accepted that FGM constitutes persecution, this was certainly not the case before the BIA's decision in Matter of Kasinga. The Immigration Judge who initially denied Ms. Kasinga's petition for asylum found that her claim did not meet the definition of persecution because FGM "is part of the tribal culture for a few ethnic groups." 219 Presumably to demonstrate a lack of nexus, he added that "all members of her ethnic tribal group are being pressured into being circumcised." 220 The reasoning in the original Kasinga opinion is strikingly similar to that utilized by modern day courts when they hold that forced marriage does not rise to the level of persecution because it is a common and culturally accepted practice. But as long as claims continue to be based on the "safer" component parts of forced marriage, courts - as well as clients and their advocates-will be denied the opportunity for their own "Kasinga moment," where forced marriage standing alone is finally recognized as per se persecution.

\section{CONCLUSION}

This Article contends that existing asylum law not only supports, but requires, adjudicators to recognize forced marriage itself as a form of persecution. Yet because this protection is not currently being afforded to survivors or those who fear the practice, the BIA and the federal courts could bring much-needed clarity to the issue by articulating a per se standard at the next available opportunity. But because women fleeing forced marriage should not have to wait until the courts have a suitable case before them, Congress should amend the Immigration and Nationality Act to classify forced marriage as a per se form of persecution, ${ }^{221}$ or the Department of Homeland Security should promulgate a rule to the

219 Matter of Kasinga, File No. A 73476 695, 12 (Oral Decision of the Immigration Judge Aug. 25, 1995), available at http://www.justice.gov/eoir/efoia/kasinga l.pdf [http://perma.cc/PY4K-9VLM].

220 Id.

221 Such action would not be without precedent. In 1996, Congress amended the statutory definition of "refugee" to effectively confer per se relief to victims of past forced sterilization, a significantly more sweeping and generous expansion of asylum law than what is suggested here. See Immigration and Nationality Act $\S 101(a)(42), 8$ U.S.C. $\S 1101$ (a)(42) (West 2013) ("For purposes of determinations under this chapter, a person who has been forced to abort a pregnancy or to undergo involuntary sterilization, or who has been persecuted for failure or refusal to undergo such a procedure or for other resistance to a coercive population control program, shall be deemed to have been persecuted on account of political opinion, and a person who has a well-founded fear that he or she will be forced to undergo such a procedure or subject to persecution for such failure, refusal, or resistance shall be deemed to have a well-founded fear of persecution on account of political opinion."). 
same effect.

Asylum law exists to provide a safe haven in the United States for individuals fleeing persecution. But in addition to providing this protection, asylum law is also a declaration of our nation's values, an area of law with which we proclaim that certain acts and actions are contrary to our collective belief system. ${ }^{222}$ We as a nation are unmistakably moving toward a broad and liberal understanding of marriage, where the freedom to choose one's spouse is recognized as a fundamental civil and human right. Marriage is a sacred and revered institution in both international law and domestic constitutional law; isn't it time for courts interpreting our asylum laws to follow suit?

222 See, e.g., Matthew E. Price, Politics or Humanitarianism? Recovering the Political Roots of Asylum, 19 Geo. Immigr. L.J. 277, 310 (2005). 